\title{
ORganized PSEUdOLEGAL \\ COMMERCIAL ARGUMENTS IN \\ CANADIAN INTER-PARTNER FAMILY LAW \\ COURT DISPUTES
}

\author{
DONALD J. NETOLITZKY*
}

\begin{abstract}
This article addresses the phenomenon of Organized Pseudolegal Commercial Arguments (OPCA) from the lens of inter-partner disputes. The author begins by briefly reviewing the history of OPCA in Canada, and then proceeds to conduct a Canada-wide survey of OPCA judgments that involve inter-spouse conflict. One of the primary cases focused on is the Alberta judgment, Meads v. Meads. The author finds that there are few OPCA judgments to draw from, which he concludes is a result of the character of OPCA pseudolegal concepts. These concepts are typically intended to target government and institutional actors, rather than private individuals, meaning that these arguments are ill suited to family law situations.
\end{abstract}

\section{TABLE OF CONTENTS}

I. INTRODUCTION . . . . . . . . . . . . . . . . . . . . . . . . . . . . . . 955

II. OPCA HISTORY AND CONCEPTS $\ldots \ldots \ldots \ldots \ldots \ldots \ldots \ldots \ldots \ldots \ldots \ldots$

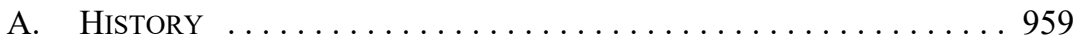

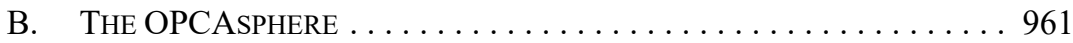

C. KEY OPCA CONCEPTS . . . . . . . . . . . . . . . . . . . . . . . 963

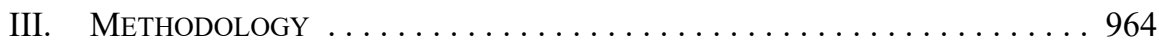

A. LOCATING OPCA JURISPRUDENCE $\ldots \ldots \ldots \ldots \ldots \ldots \ldots \ldots \ldots$

B. OPCA INTER-PARTNER LEGAL DiSPUTES $\ldots \ldots \ldots \ldots \ldots$

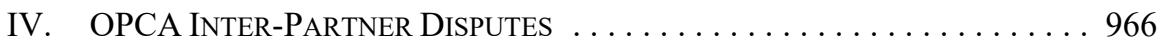

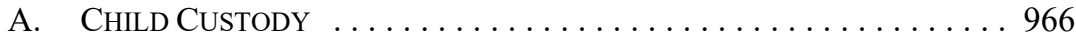

B. Property Disputes, AND Child AND SPOUSAL SuPPORT . . . . . . . . 972

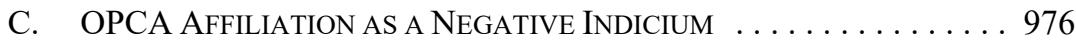

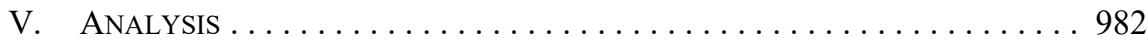

A. OPCA THEORY SUPPORTS INTER-PARTNER OBLIGATIONS . . . . . 984

B. NON-"STRAWMAN" OPCA STRATEGIES . . . . . . . . . . . . . . . 987

C. OPCA ARGUMENTS In ChILd CUSTOdy Disputes . . . . . . . . . . . 989

D. OPCA AFFILIATE SRLS AND PARENTAL FITNESS $\ldots \ldots \ldots 99$

E. ATtRiButes OF OPCA LitigAnTS

IN FAMILY LAW DISPUTES $\ldots \ldots \ldots \ldots \ldots \ldots \ldots . \ldots \ldots \ldots . \ldots \ldots \ldots$



\section{INTRODUCTION}

In Canada, 2012-2013 marked a watershed for public exposure to pseudolegal beliefs and communities. This period saw the first mass media reporting on the Freeman-on-the-Land movement, ${ }^{1}$ widely publicized examples of illegal property seizures in Alberta by pseudolaw

PhD Microbiology, University of Alberta, 1995; LLB, University of Alberta, 2005. Legal Counsel for the Alberta Court of Queen's Bench. The views expressed in this article are those of the author, and not those of any other member of the Court of Queen's Bench, or the Court itself.

See e.g. Interview of Robert Arthur Menard by Adrienne Arsenault (29 February 2012) in "Finding the Freemen" on The National, CBC Television, online: $<$ cbc.ca/news/canada/freemen-movement-capturescanadian-police-attention-1.1262159>. 
proponents, $^{2}$ and the release of an unusual divorce judgment, Meads v. Meads, which collected and reviewed Canadian jurisprudence that responded to litigants who claimed extraordinary rights and immunities based on unorthodox but legal-sounding schemes. ${ }^{3}$ Associate Chief Justice Rooke in Meads called these "Organized Pseudolegal Commercial Arguments" (OPCA). ${ }^{4}$

One of the first legal academic responses to the OPCA phenomenon was a blog post by Jonnette Watson Hamilton that reviewed Meads and highlighted three issues that Hamilton indicated deserve further research and scholarship: (1) why had the OPCA phenomenon remained undetected and uninvestigated; (2) whether laypersons "accidentally" adopt OPCA litigation strategies; and (3) a possible linkage between family law and OPCA litigation. ${ }^{5}$

Hamilton's first question can be largely explained by three factors. First, OPCA litigation is "clustered [in] geography, time, and intent." This dispersion impedes recognition of the scope and unity of the phenomenon. Second, OPCA litigation is notoriously difficult to identify and review via conventional legal research techniques. ${ }^{7}$ Last, the legal domains that commonly involve OPCA litigants, such as debt collection and income tax evasion, are not ones which appear to attract much academic interest. For example, the very important Klundert tax evasion judgment series ${ }^{8}$ has attracted little comment, ${ }^{9}$ even though Canada, as a result, took a markedly different approach from the United States to the mens rea element of tax evasion. ${ }^{10}$

As for naive laypersons adopting OPCA strategies, this appears unlikely given these ideas generally circulate in highly paranoid, politically extremist, and introspective marginalized social communities, with certain limited exceptions. ${ }^{11}$

See Donald J Netolitzky, "The History of the Organized Pseudolegal Commercial Argument Phenomenon in Canada" (2016) 53:3 Alta L Rev 609 at 628-29 [Netolitzky, "History of the OPCA"]. Though typically described as "Freeman" activities, these incidents were actually conducted by a different pseudolegal group, the Tacit Supreme in Law Court and its affiliate subgroups.

2012 ABQB 571, [2013] 3 WWR 419 [Meads].

Ibid at para 1 .

Jonnette Watson Hamilton, "The Organized Pseudolegal Commercial Argument (OPCA) Litigant Case" (30 October 2012), ABlawg (blog), online: <ablawg.ca/the-organized-pseudolegal-commercialargument-opca-litigant-case/>.

Netolitzky, "History of the OPCA," supra note 2 at 611 [emphasis in original]; see also note 19, below. See Part III.A, below.

The Klundert litigation involved no less than three trials and subsequent decisions by the Ontario Court of Appeal: $R v$ Klundert (2004), 242 DLR (4th) 644 (Ont CA), leave to appeal to SCC refused, 30578 (24 March 2005); $R v$ Klundert, 2008 ONCA 767, 93 OR (3d) 81, leave to appeal to SCC refused, 32936 (9 April 2009); $R v$ Klundert, 2011 ONCA 646, 107 OR (3d) 561, leave to appeal to SCC refused, 34558 (5 April 2012). This litigation was only recently exhausted when the Federal Court of Appeal confirmed Klundert's 1993-1996 income tax reassessments (Klundert v R, 2014 FCA 155, 461 NR 323), and allocated seized assets (Klundert $v$ R, 2014 FCA 156, 464 NR 196). The three Ontario Court of Appeal Klundert judgments are together a cornerstone on how Canadian courts approach tax evasion flowing from schemes that allegedly defeat income tax obligations.

9 Only one Canadian paper comments on any Klundert income tax litigation: Marie Comiskey \& Matthew Sullivan, “Avoidance, Deception and Mistake of Law: The Mens Rea of Tax Evasion" (2006) 51:3 Crim LQ 303. Notably, the authors are counsel for the federal government.

10 Joshua P Weir, "Sovereign Citizens: A Reasoned Response to the Madness" (2015) 19:3 Lewis \& Clark L Rev 829 provides a very helpful review on this subject.

11 See Netolitzky, "History of the OPCA," supra note 2 at 635-36; Donald J Netolitzky, "Organized Pseudolegal Commercial Arguments [OPCA] in Canada; an Attack on the Legal System" (2016) 10 JPPL 137 at 175-79 [Netolitzky, "Attack on the Legal System"]. 
That leaves the frequency and role of OPCA concepts in family law disputes. Hamilton observes that "[i]t appears that family law is one of the contexts in which OPCA litigants can frequently, perhaps even disproportionately, be found," and continues to "suggest research into OPCA litigation in the family law context is needed." 12

This interest in the possible interplay of OPCA and family law litigation has an obvious basis. The dramatic, Canada-wide increase in self-represented litigants or "SRLs,"13 particularly in family law, ${ }^{14}$ has been the subject of broad commentary by lawyers, the judiciary, legal academics, and the popular media. Some sources estimate that the majority of recent Alberta family law trials have at least one SRL participant. ${ }^{15}$

Julie Macfarlane of the National Self-Represented Litigant Project(NSRLP) characterizes interactions between SRLs and the judiciary and lawyers as adversarial and even abusive. ${ }^{16}$ She has, along with other academics, expressed concern that judges would be unable (or unwilling) to distinguish OPCA litigants from "conventional" SRLs, and has warned that courts and legal professionals are opportunists who would blur these groups "to ridicule and discipline authentic self represented litigants." ${ }^{.17}$ Therefore, unlike Hamilton, Macfarlane sees the SRL and OPCA litigant communities as entirely distinct, and argues that any allegation of an overlap between these two types is fundamentally unfair.

This article addresses that disagreement, and conducts a Canada-wide survey of reported OPCA judgments that involve inter-spouse conflict. Legal disputes of this kind are very uncommon, and only represent a very small fraction (under 3 percent) of identified OPCA jurisprudence. ${ }^{18}$ Somewhat paradoxically, Meads is one of them. More striking yet is that in three of the identified ten disputes the OPCA litigant did not employ OPCA strategies, but instead accepted court authority — these were, in effect, non-OPCA OPCA litigants.

This result can be explained by the objectives, litigation targets, and pseudolegal theories of commonplace OPCA schemes. Pseudolaw is typically employed in four ways: as a "get out of jail free" card for criminal accused and offenders, in spurious pseudolaw-based

\section{Supra note 5 .}

This population is referred to as "pro se litigants" in the US, and "litigants in person" in the UK. See John-Paul E Boyd \& Lorne D Bertrand, "Self-Represented Litigants in Family Law Disputes: Contrasting the Views of Alberta Family Law Lawyers and the Judges of the Alberta Court of Queen's Bench" (Calgary: Canadian Research Institute for Law and the Family, 2014); Julie Macfarlane, "The National Self-Represented Litigants Project: Identifying and Meeting the Needs of Self-Represented Litigants: Final Report” (2013) National Self-Represented Litigants Project Working Paper.

Boyd \& Bertrand, ibid at 1; Macfarlane, ibid at 32-34.

For example, in the use of summary judgment procedures: Julie Macfarlane, Katrina Trask \& Erin Chesney, "The Use of Summary Judgment Procedures Against Self-Represented Litigants: Efficient Case Management or Denial of Access to Justice?” (2015) NSRLP Working Paper.

17 Julie Macfarlane, “Avoiding Conflation: OPCAs and Self Represented Litigants"(6 October 2012), The National Self-Represented Litigants Project(blog), online: <representingyourselfcanada.com/avoidingconflation-opcas-and-self-represented-litigants/>. See also Julie Macfarlane, "The 'Scourge' of SelfRepresentation?” (12 January 2013) The National Self-Represented Litigants Project (blog), online: $<$ representingyourselfcanada.com/the-scourge-of-self-representation/>; Alice Woolley, "The Top Ten Canadian Legal Ethics Stories - 2012" (3 January 2013), ABlawg (blog), online: <ablawg.ca/the-topten-canadian-legal-ethics-stories-2012/> (where she identifies this as a significant legal ethics issue); Amy Salyzyn, "Canada: Foreclosures, Freemen, Foreign Law Schools and the Continuing Search for Meaningful Access to Justice" (2013) 16:1 Leg Ethics 223.

18 See Parts III.A and V, below, for why this value should be viewed with caution. 
attacks, as a tax evasion tool, and in debt elimination. ${ }^{19}$ These scenarios usually have the OPCA litigant engage a state or institutional actor. The ubiquitous "Strawman" motif is irrelevant in person-to-person interactions, and OPCA theory supports, rather than subverts, court enforcement of interpersonal bargains. ${ }^{20}$ Meads itself follows this pattern. This keystone judgment is typically described as a family law divorce dispute, but closer examination reveals that the OPCA litigant, Dennis Meads, did not in fact deny his matrimonial and parental obligations, but instead attempted to discharge those obligations via pseudolegal processes. This was a debt relief action.

OPCA inter-partner litigation is a comparatively minor facet of the OPCA phenomenon as a whole. Even more interesting is that certain OPCA litigants are ordinary "conventional" SRLs, at least in the context of family litigation. It simply happens that these SRLs collaterally deny government authority, hate law enforcement, believe they have a right to ignore legislation, and are often involved in criminal misconduct. They, nevertheless, may otherwise attempt to be lawful parents.

\section{OPCA HISTORY AND CONCEPTS}

The Meads decision provides a starting point for recent investigation of the Canadian OPCA phenomenon via its synthesis and review of Canadian litigation and court experiences, and provides a broader and contextual portrait of the OPCA domain, as well as its social structure, unique characteristics, dominant personalities, pseudolegal concepts, and court countermeasures. "OPCA gurus" sell pseudolegal schemes to OPCA litigants and OPCA affiliates (persons who adhere to but do not necessarily use those concepts in legal disputes or proceedings). ${ }^{21}$ These individuals self-organize in "OOPCA movement[s] ... group[s] that [use] common OPCA strategies and who hold or adopt a shared social perspective and typically conspiratorial alternative history. ${ }^{.22}$ Meads is not, however, a comprehensive review of the OPCA phenomenon in Canada. The restricted data sources available omitted important facts, such as certain Canadian OPCA movements and gurus, and this decision significantly understates the lengthy history of OPCA activities as a whole.

Subsequent publications document the history of the Canadian OPCA phenomenon, some of its key concepts, and its potential for illegal and violent consequences. ${ }^{23}$ The growing appreciation that OPCA litigation and litigants represent a distinct category has led to specific investigation and commentary on this subject, both inside and outside Canada. ${ }^{24}$

Defense to criminal prosecution composed 302 of 725 reported judgments, income tax litigation composed 139 of 725 , debt elimination made up 101 of 725 , and spurious attacks to enforce fictitious OPCA-based rights made up 92 of 725 . A large proportion (63 percent) of criminal defence cases resist prosecution of tax offences. See also Part III.A, below.

20 See Netolitzky, "History of the OPCA," supra note 2 at 633-35; Netolitzky, "Attack on the Legal System," supra note 11 at 144-45. In Meads, supra note 3, this concept is discussed at paras 417-46 as the "double/split person" motif.

Netolitzky, "History of the OPCA," ibid at 611.

Ibid at 612 .

See Netolitzky, "History of the OPCA," ibid; Netolitzky, "Attack on the Legal System," supra note 11. First-hand experience has lead to "after action" commentary and analysis by involved lawyers (Jason K Yamashita, "Utility Dealings with Freemen-on-the-Land and Others Raising 'Organized Pseudo-Legal Commercial Arguments"” (2015) 3:2 Energy Regulation Q 51) and court personnel (Donald J Netolitzky \& John D Rooke, "Organised Pseudolegal Commercial Argument (OPCA) Litigants: New Challenges in the Internet Age" (Paper delivered at the CIAJ National Roundtable on the Vexatious Litigant, Toronto, 10 March 2016) [unpublished]. Similarly, Commonwealth commentators outside Canada have 
Research by mental health ${ }^{25}$ and social science professionals ${ }^{26}$ has provided a better understanding of OPCA litigants, as well as their beliefs, society, and associated risks.

A brief introduction to OPCA history and OPCA theories is helpful to understand OPCA inter-partner disputes. This review will focus on Canada. The US has a lengthy OPCA history, which has led to substantial commentary by academics, ${ }^{27}$ government bodies, and other agencies. However, US and Canadian OPCA litigation is quite different in that US Sovereign Citizen concepts were developed in rural farm and blue-collar communities with libertarian, evangelical religious, and often racist beliefs, to counter perceived excessive state interference or intrusion into personal activities via taxation, gun control, civil rights, and education curriculums. ${ }^{28}$

A dramatic shift in focus occurred when Sovereign Citizen ideas were introduced into Canada via the Freeman-on-the-Land movement. OPCA strategies were initially limited to parent versus state child custody disputes. This gave the Freeman movement and its successors a different orientation, one that is much more amenable to applying OPCA concepts in family law disputes since Freemen explicitly view children as property, and have an expanded mythos on that subject and its implications. ${ }^{29}$

\section{A. HISTORY}

The OPCA phenomenon in Canada is divided into two broad subcomponents: the Detaxers, and the Freemen-on-the-Land. The Detaxers surged then collapsed in the 2000s, and are now all but extinct. Detaxers focused on mechanisms that (purportedly) eliminated income tax and GST obligations. This greed-driven movement was able to accommodate both right- and left-wing narratives. The Detaxer movement disintegrated when Canadian courts systematically rejected its schemes. ${ }^{30}$

documented how the Canadian OPCA phenomenon has taken root and developed in their jurisdictions: New Zealand: Thomas Bloy, "Pseudolaw and Debt Enforcement" [2013] NZLJ 47; Republic of Ireland, Northern Ireland and the UK: Tomás Keys, "Freeman on the Land and Other Organised Lay Litigant Groups - Part 1" (2014) 10 Commercial L Practitioner 230; Tomás Keys, "Freeman on the Land and Other Organised Lay Litigant Groups - Part 2" (2014) 11 Commercial L Practitioner 256; Garret Sammon, "'Organised Pseudo-legal Commercial Argument' Litigation: Challenges for the Administration of Justice in Ireland" (2015) 38:1 Dublin ULJ 85.

$25 \quad$ See Jennifer Pytyck \& Gary A Chaimowitz, "The Sovereign Citizen Movement and Fitness to Stand Trial" (2013) 12:2 Intl J Forensic Mental Health 149; George F Parker, "Competence to Stand Trial Evaluations of Sovereign Citizens: A Case Series and Primer of Odd Political and Legal Beliefs" (2014) 42:3 J American Academy Psychiatry \& L 338.

26 See Stephen A Kent \& Robin D Willey, "Sects, Cults, and the Attack on Jurisprudence" (2013) 14:2 Rutgers JL \& Religion 306; Stephen A Kent, "Freemen, Sovereign Citizens, and the Challenge to Public Order in British Heritage Countries" (2015) 6 Intl J Cultic Studies 1; Angela W Eke et al, "Threats, Approach Behavior, and Violent Recidivism Among Offenders Who Harass Canadian Justice Officials" (2014) 1:3 J Threat Assessment \& Management 188; J Reid Meloy, "The Lone Terrorist in the Workplace" (16 December 2014), Psychology Today (blog), online: <https://www.psychology today.com/blog/the-forensic-files/201412/the-lone-terrorist-in-the-workplace>.

27 See Netolitzky, "Attack on the Legal System," supra note 11, n 28 for a list of 14 academic papers and one judgment that discuss US OPCA phenomena. Most of these resources focus on the Sovereign Citizen movement and its precursors; the second major US OPCA movement, the Moors, seems understudied. None of these publications focus on family law subjects. Pytyck \& Chaimowitz, supra note 25 at 150 .

UK OPCA concepts, including those that involve children, largely derived from Canadian Freeman precursors. See e.g. Child Protection Resource (blog), online: <childprotectionresource.online/category/ the-freeman-and-common-law/ $>$. Note that the focus is on child apprehension scenarios. See also notes 35-36 and accompanying text, below.

$30 \quad$ Netolitzky, " History of the OPCA," supra note 2 at 616-24. 
The Freemen-on-the-Land, the second broad-based and now dominant Canadian OPCA movement, first emerged in British Columbia "[a]round the year 2000 ... in ... politically leftist, 'green,' anti-globalization, [social activist, marijuana advocacy,] and anti-government communities." ${ }^{31}$ This OPCA movement was effectively the sole creation of a single guru, Robert Arthur Menard, ${ }^{32}$ a British Columbia street comedian who claimed that all government authority may be defeated if an individual withdraws his or her consent to be governed. ${ }^{33}$ Freeman-on-the-Land concepts have a broad application, allegedly permit Freemen to evade practically any government obligation or authority, and yet, still give Menard's followers a right to extract conventional (and extraordinary) services from the remainder of Canadian society. Perhaps unsurprisingly, this earned Freemen a popular nickname: "Freeloaders-on-the-Land." 34

However, as previously mentioned, Menard initially focused on his rights concerning children. His first book, Your Child or Her Life!: Deception and Evil in the Ministry of Children, Family and Community Development, explained how parental control and ownership of children is subverted when a child is registered and obtains a birth certificate, as that abandons "ownership and control of the person you created and associated with your offspring and the government seizes it under salvage laws." 35 This permits state action. These child apprehension concepts became a secondary topic in his later texts, as Menard's focus shifted to globally disabling government, law enforcement, and court authority by "denying consent." 36

The Freeman-on-the-Land movement grew throughout the 2000s, but is now in considerable distress and upheaval. Menard failed to deliver on his many schemes. ${ }^{37}$ In 2014 , he was arrested in Ontario for multiple counts of impersonating a peace officer, ${ }^{38}$ and then absconded. ${ }^{39}$ Menard's guru heir apparent, Dean Clifford, was arrested in 2013 on grow-op

\section{$31 \quad$ Ibid at 624 .}

32 See ibid at 624-26; Netolitzky, "Attack on the Legal System," supra note 11 at 145-60. Menard is also discussed in Meads, supra note 3 at paras 121-24. He has a minimal litigation footprint, appears to avoid court proceedings both personally and as an advisor, and has concealed his in-court failures.

33 Robert-Arthur Menard, With Lawful Excuse (Elizabeth Anne Elaine Society and Freddie Freepickle Productions, 2011) [Menard, Lawful Excuse] at 37, 141-43, 167 (reviewed in Netolitzky, "Attack on the Legal System," ibid at 150-51). This concept and procedure parallels Sovereign Citizen techniques. See Wilson Huhn, "Political Alienation in America and the Legal Premises of the Patriot Movement" (1999) 34:3 Gonz L Rev 417 at 431-33; Michelle Theret, "Sovereign Citizens: A Homegrown Terrorist Threat and Its Negative Impact on South Carolina" (2012) 63:4 SCL Rev 853 at 864-66; Francis X Sullivan, "The 'Usurping Octopus of Jurisdictional/Authority': The Legal Theories of the Sovereign Citizen Movement" [1999] Wis L Rev 785 at 801-804, 809-11; United States v Phillips, 2014 WL 2801323 at $14-15$ (ND Ill).

34 This phrase appears repeatedly in the public comments added to OPCA-related new stories, and also in the title of an article in The Economist: "Freeloaders on the Land: American-Style Anti-Government Eccentrics Take Root in Canada," The Economist (12 October 2013), online: <www.economist.com/ news/americas/21587804-american-style-anti-government-eccentrics-take-root-canada-freeloadersland $>$.

35 Robert Arthur, Your Child or Her Life! Deception and Evil in the Ministry of Children, Family and Community Development (Elizabeth Anne Elaine Society) at 11.

36 Robert Arthur Menard, 13 Things the Government Doesn't Want You to Know (Vancouver: Elizabeth Anne Elaine Society and POOPIE, 2003) at 8; Robert Arthur Menard, Bursting Bubbles of Government Deception (Vancouver: Elizabeth Anne Elaine Society and Freddy Freepickle Productions, 2004) at 3-9; Menard, Lawful Excuse, supra note 33 at 16-17.

See Netolitzky, "History of the OPCA," supra note 2 at 626.

Criminal Code, RSC 1985, c C-46, s 130.

$R v$ Menard (9 February 2015), Toronto 4813998143500374700, 4813998143500427000 (Ont Ct J). In 2015, Menard unsuccessfully sued to have himself declared a peace officer (Menard $v R$ (18 March 2015), Montreal T-43-15 (FC)) in what appears to be a collateral attack on his criminal prosecution. 
and firearms charges. He was convicted and sentenced to three years incarceration. ${ }^{40}$ Clifford's reputation, too, has suffered with the obvious failure of his ideas during his 16 month pretrial detention and at trial. The now-disintegrating Freeman movement has attracted the attention of many new gurus who scavenge for its remaining affiliates.

\section{B. THE OPCASPHERE}

Despite their gurus' impotent litigation performance, the appearance of well-developed anti-OPCA jurisprudence, ${ }^{41}$ and repeated in-court failures, a core of persons who adopted Freeman and related OPCA concepts remain surprisingly committed to an unusual funhouse mirror perspective of pseudolegal concepts and paranoid, conspiracy-ridden anti-government belief. This can only be explained by their membership in an introspective and marginalized community which occupies a unique social space, the OPCAsphere. ${ }^{42}$

The OPCAsphere is a social community of OPCA affiliates. OPCA affiliates are, in certain senses, a disparate group, and include retirees, professionals, criminals, academics, blue-collar workers, farmers, and Aboriginal persons. ${ }^{43}$ While their political, philosophical, and religious perspectives are diverse, most occupy the more unorthodox and extreme ends of commonplace belief spectrums.

Almost all OPCAsphere residents exhibit a strong affinity for conspiracy, and, in particular, a belief that government and social institutions are controlled either by a hidden hand, or an intensely malevolent and corrupt leadership. Rather strangely, sometimes entirely contradictory beliefs about these dark actors coexist with little apparent conflict. ${ }^{44}$ This makes the OPCAsphere an example of what Michael Barkun calls "improvisational millennialism," a pattern of conspiratorial belief that does not arise from a single ideological tradition, but instead scavenges a collage of conspiracy from diverse, typically borrowed, sources and "stigmatized knowledge." 45

$R v$ Clifford (8 January 2016), Winnipeg CR14-01-33786 (Man QB).

Meads, supra note 3 is the leading example, but that judgment is only one of a phalanx of recent decisions that rebut OPCA concepts in a manner that directly challenges the OPCAsphere construct, including: Fearn v Canada Customs, 2014 ABQB 114, 586 AR 23 [Fearn]; ANB v Hancock, 2013 ABQB 97, 557 AR 364 [ANB]; $R$ v Petrie, 2012 BCSC 2109, 2012 BCSC 2109 (CanLII); $R \vee$ Petrie, 2012 BCSC 2110, 2012 BCSC 2110 (CanLII); Bossé v Farm Credit Canada, 2014 NBCA 34, 419 NBR (2d) 1, leave to appeal to SCC refused, 36026 (11 December 2014) [Bossé]; Alberta Treasury Branches $v$ Nielson, 2014 ABQB 383, 14 CBR (6th) 177 [Nielson]; Bank of Montreal v Rogozinsky, 2014 ABQB 771, 603 AR 261 [Rogozinsky]; Rubbert v Boxrud, 2014 SKQB 221,450 Sask R 147 [Rubbert]; Fiander $v$ Mills, 2015 NLCA 31, 368 Nfld \& PEIR 80; Re Boisjoli, 2015 ABQB 629, 29 Alta LR (6th) 334 [Boisjoli]; Servus Credit Union Ltd v Parlee, 2015 ABQB 700, 7 Admin LR (6th) 321 [Parlee]; Crossroads-DMD Mortgage Investment Corporation v Gauthier, 2015 ABQB 703, 28 Alta LR (6th) 104.

42 Netolitzky, "History of the OPCA," supra note 2 at 635-36; Netolitzky, "Attack on the Legal System," supra note 11 at $143-45$.

Meads, supra note 3 at para 68

Netolitzky, "Attack on the Legal System," supra note 11 at 185, 189.

Michael Barkun, A Culture of Conspiracy: Apocalyptic Visions in Contemporary America, 2nd ed (Berkeley: University of California Press, 2013) at 18-38. Barkun directly, though briefly, discusses Sovereign Citizens as an improvisational millennialist phenomenon at 196-98. 
One example are the various competing ${ }^{46}$ OPCAsphere theories where a myriad of alternative cabals pull the strings, be it the Illuminati, ${ }^{47}$ "the Banksters," 48 an international Jewish conspiracy, ${ }^{49}$ or even a species of extraterrestrial subterranean shape-shifting lizards. ${ }^{50}$ The common thread is that someone else is in control, this control is concealed, and the uninformed majority are nothing more than "sheeple" who are manipulated by mainstream media, academia, government stooges, and paid shills. While fear permeates the OPCAsphere, so does a sense of pride and superiority. Many OPCAsphere residents see themselves as a social vanguard or as revolutionaries. Others are content to withdraw and allow the impending catastrophe to run its course. ${ }^{51}$

The OPCA phenomenon is a social one. Forensic psychiatrists who have investigated persons who express and advance OPCA concepts conclude OPCA ideas and their broader context represent a kind of extreme political belief that is reinforced in marginal social groups. ${ }^{52}$ These beliefs are so unusual that OPCA affiliates may be misdiagnosed as mentally ill. ${ }^{53}$ OPCA beliefs, unusual associated behaviour, and speech patterns simulate delusion. Sociologists Stephen Kent and Robin Willey draw parallels between the OPCA phenomenon and religious cults: each share a distance from and distain for government and court structures. $^{54}$

However, not all OPCA litigation is conducted by persons who occupy the OPCAsphere. Some OPCA litigants are clearly not motivated by ideology or the OPCAsphere's curious political and conspiratorial narrative. Instead, they only use these pseudolegal strategies as a mechanism for tangible benefit. This subgroup, the Mercenary OPCA Litigants, predictably discontinues OPCA tactics when these techniques prove ineffective. ${ }^{55}$

Barkun, ibid, observes at 233-34 that this seeming inconsistency is more apparent than real, since it is easy for controlling conspiracies to coexist in improvisational millenialism. Each is simply a shell behind which lurks yet another puppeteer.

The historical Illuminati was an 18th century secret society, however, popular conspiracy theorists argue this group still exists and plots to exert global control. Other fraternal organizations and secret societies such as the Freemasons are also popular "hidden hands." A portmanteau of "bankers" and "gangsters." Both secular (the Rothschild banks, the Bilderberg Group) and religious (the Vatican) banking conspiracies are popular.

Ocupational Government, or "ZOG." This is a popular extreme right-wing motif, particularly common in Sovereign Citizen circles. See Nigel James, "Militias, The Patriot Movement, and the Internet: The Ideology of Conspiracism" in Jane Parish \& Martin Parker, eds, The Age of Anxiety: Conspiracy Theory and the Human Sciences (Oxford: Blackwell, 2001) at 70-71.

This preposterous but surprisingly widespread (in New Age/conspiracy circles) concept is chiefly propagated by UK former sports broadcaster David Icke. See David Icke, The Biggest Secret: The Book That Will Change the World, 2nd ed (Scottsdale: David Icke Books, 1999). Icke identifies numerous prominent politicians, entertainers, and royalty as reptiles. This is only perhaps the most flamboyant of Icke's claims. In many senses, Icke advances stereotypic financial conspiracy schemes. Icke is closely related to the Canadian OPCA community. See Warman v Icke, 2009 CanLII 43943 (Ont Sup Ct J) which involved key OPCA guru personalities Tom "UsuryFree" Kennedy and David Kevin Lindsay. See e.g. Huhn, supra note 33 at 435 .

Pytyck \& Chaimowitz, supra note 25; Parker, supra note 25.

Pytyck \& Chaimowitz, ibid at 151-53; Parker, ibid at 346-47. An Ontario resident, Rodney Wayne King, who fired on and injured RCMP officers during a foreclosure, is a potential Canadian misdiagnosis scenario: see Netolitzky, "Attack on the Legal System," supra note 11 at 168-71.

Kent \& Willey, supra note 26.

Netolitzky, "Attack on the Legal System," supra note 11 at 179-81. 
Some OPCA litigation may be initiated by individuals who are simply unaware of the unorthodox nature of these schemes. This subpopulation, the Accidental OPCA Litigants, is rare and also transient. ${ }^{56}$

In Canada, OPCA concepts are, at best, marketed to their customers in a rather amateurish manner, and are presented as secret or hidden knowledge, rather than legitimate legal techniques. The more plausible Accidental OPCA Litigant scenario is, instead, where an OPCA scheme is implemented by a guru and its substance is concealed from the OPCA litigant. ${ }^{57}$ This pattern is uncommon in Canada.

The result is that persistent OPCA litigation is usually conducted by residents of the OPCAsphere. Mercenary and Accidental OPCA Litigants are, at some level, rational actors who abandon these strategies when they prove ineffective.

\section{KEY OPCA CONCEPTS}

While Canadian OPCA litigants deploy a sometimes bewildering variety of pseudolegal motifs, there are three key concepts which are both generally accepted by and critical to the modern OPCAsphere's pseudolaw.

First, the "Strawman" double or split person concept claims that in law, an individual has two halves: a physical "flesh and blood" human being, and an incorporeal half that has many names, including a "person," a "Strawman," a "legal fiction," or a trust. ${ }^{58}$ Government authority is restricted to the incorporeal aspect and is otherwise illegitimate, deceptive, and restrictive of innate rights. Individuals can purportedly "opt out" of this tyranny with the correct steps that "unshackle" a human being from their "Strawman" doppelganger. Doing so disrupts the "Strawman" parasitic link, and makes the physical person only subject to some other kind of law, often called "common law.",59

A second and related pseudolegal concept is that binding relationships can only result from mutual agreement or contract. This "everything is a contract" motif is usually employed to reject legislation, which allegedly is nothing more than a government offer to contract. Governments are simply corporations in disguise. OPCA litigants argue they are not subject to these rules since they did not contract into legislation, and have rejected or terminated any existing human-to-government contracts, or "joinder." 60

The last is a discrete legal error: a misapprehension that silence can indicate acceptance of a contract. OPCA litigants frequently employ foisted unilateral agreements: contract offers

Ibid at $176-79$.

See e.g. the Gold Shield Alliance scheme reviewed in Nielson, supra note 41 at paras 8-29. Customers hired Gold Shield Alliance to "zero" debts, but never received copies of the OPCA documents Gold Shield Alliance sent to lenders and the courts.

See supra note 20.

This "mutant" version of the term "common law" is discussed in Meads, supra note 3 at paras 326-27, and more generally in Fearn, supra note 41 at paras 46-64, 94. See also James M Vaché \& Mark Edward DeForrest, "Truth or Consequences: The Jurisprudential Errors of the Militant Far-Right" (1997) 32:3 Gonz L Rev 593 at 600-607; Robert C Black, “Constitutionalism': The White Man's Ghost Dance" (1998) 31:2 John Marshall L Rev 513; Susan P Koniak, "When Law Risks Madness" (1996) 8:1 Cardozo Stud L \& Lit 65 at 71-73 (for this subject in a US context). 
that stipulate that the recipient is deemed to agree with its terms unless a positive step is taken to refuse or refute the offer. ${ }^{61}$ While this pseudolegal tool has broad potential application, the most commonly encountered forms are the Three/Five Letters strategy to defeat debts, "fee schedules" that set penalties for government actors, and as a mechanism that allegedly crystallizes a fact or conclusion. ${ }^{62}$

\section{Methodology}

Prior investigations identified 725 reported Canadian court judgments that:

1. either had a litigant:

a. employ OPCA concepts, or

b. display OPCA litigation indicia, or;

2. reported on a proceeding where OPCA concepts or indicia were identified.

This set of decisions is the "OPCA Judgment Dataset."

\section{A. LOCATING OPCA JURISPRUDENCE}

Assembling the OPCA Judgment Dataset required unusual research steps because few citations interlink these decisions and the fingerprints of OPCA litigation are often subtle. Many judgments do not classify the OPCA litigant or recognize the OPCA litigant as part of a larger phenomenon, and may only provide an incomplete or partial explanation of the OPCA strategy and concepts in play. Prior to 2012, judges often concluded OPCA litigants were isolated eccentrics, and therefore disposed of these matters in a perfunctory manner. Combined, these factors make OPCA judgments an elusive research target.

This is not a subject area where conventional keyword database searches are particularly helpful, nor is the process of "noting up" citations all that effective. For example, post-2012, Meads provides an obvious starting point to identify OPCA decisions. Between 2013-2015, 79 Canadian OPCA subject decisions cite Meads, but this author has identified a total of 244 OPCA-related decisions for that period. Commonly used labels are also of limited assistance. Of the 225 OPCA-related decisions identified between 2005-2011, only 19 judgments include identifying language like "Freeman-on-the-Land," "Sovereign Citizen," "Sovereign Man," or "Detaxer."

The majority of OPCA-related decisions were located by a variety of searches that target unusual motifs, items, and arguments, either alone or in combination. Some language used by OPCA litigants is highly atypical, to the point that any appearance will likely indicate OPCA were employed. For example, "tacit procuration" is a unique OPCA term linked to the Three/Five Letters foisted unilateral agreement scheme. ${ }^{63}$ Similarly highly specific

Ibid; Rogozinsky, supra note 41 at paras 48-54; Perreal v Knibb, 2014 ABQB 15, 8 Alta LR (6th) 55 [Perreal]; Boisjoli, supra note 41 at paras 49-57; Netolitzky, "Attack on the Legal System," supra note 11 at $150-54$.

${ }_{63}$ See Rogozinsky, ibid at para 25. A CanLII search with this term returns seven hits, all of which are OPCA litigation (as of publication). 
phrases such as "accept for value" and "truth in commerce," and unique document titles such as a "Notice of Understanding, Intent, and Claim of Right" ${ }^{64}$ provide good results.

Reference to unusual authorities and legislation is also useful, for example "Magna Carta," "Statute of Westminster 1931," and "Attorney General of Nova Scotia v Attorney General of Canada, [1951] SCR 31" return a significant number of OPCA decisions, but the OPCA fraction must be manually identified from a larger collection of conventional litigation. The names of personalities and organizations in OPCA culture are useful probes, for example, Detaxer guru "David Kevin Lindsay" and the "Paradigm Education Group."

However, many identified OPCA decisions were not located via database searches, but instead with information gleaned from other sources, such as OPCA social media sites and Internet forums, media reports of OPCA activities, and data extracted from OPCA documents. Names and atypical terminology identified in this way could then be used to search reported cases. The result is that many OPCA topic judgments were identified by "chaining." For example, this author observed an OPCA document that invoked the now abolished common law writ of coram nobis. ${ }^{65}$ Searching with that term then located a 2001 Alberta debt-related proceeding involving an OPCA litigant, Pat Whitfield, that resulted in several judgments. ${ }^{66}$ Many OPCA litigants are involved in a range of OPCA-related activities. Searching with Whitfield's name identified a series of OPCA Detaxer judgments. ${ }^{67}$ Similarly, OPCA litigants often collaborate with one another. The first Whitfield debt-related judgment saw Whitfield rely on a foisted "administrative adjudication" by a "Harvey R. Jaehn." ${ }^{68}$ Jaehn's name then led to further OPCA jurisprudence. ${ }^{69}$

The "organic" rather than "systematic" nature of this process means, with absolute certainty, that there remain many additional reported but as of yet unidentified OPCA decisions.

\section{B. OPCA INTER-PARTNER LEgAL DisPuteS}

Of the 725 cases in the OPCA Judgment Dataset, 39 reported judgments were identified where the court was required to investigate or comment on a dispute that related to:

1. the custody of, access to, or support for children;

2. the division of matrimonial or common law relationship property;

64 Variations on this title mean a search with both phrases "notice of understanding" and "claim of right" is a more useful approach, scoring 13 hits on CanLII with 100 percent accuracy (as of publication).

$65 \quad$ See $R v$ Reddick (1992), 13 BCAC 239 (CA); Re Walsh, [2012] NIQB 82. This legal concept survives in the US, which probably explains its appearance; this Canadian OPCA document had copied US materials.

$66 \quad$ Whitfield v Chrysler Credit Canada Ltd, 2001 ABQB 5, 2001 ABQB 5 (CanLII) [Whitfield 1]; Whitfield v Chrysler Credit Canada Ltd, 2001 ABQB 497, 294 AR 376.

67 Re Whitfield, 2001 FCT 777, [2001] 3 CTC 260; Minister of National Revenue $v$ Whitfield, 2002 FCT 663, [2002] 3 CTC 436; Minister of National Revenue $v$ Whitfield, 2002 FCA 300, [2002] 4 CTC 29. Whitfield 1 , supra note 66 at para 7.

69 Krueger $v$ Jaehn, 2000 ABQB 903, 2000 ABQB 903 (CanLII) [Krueger]. The OPCA character of this litigation was confirmed by "Accepted for Value" ("A4V") documents located on file. 
3. spousal or partner support; or

4. enforcement of an order related to these subjects.

Nineteen of these decisions involved inter-partner disputes (the OPCA Inter-Partner Dispute Judgments). The remaining 20 decisions were legal disputes between parents and state actors: either state apprehension of children, or state-mediated collection of overdue child support payments.

This author has identified 47 Canadian administrative tribunal decisions that have an OPCA aspect. None relate to family law subjects.

The OPCA Inter-Partner Dispute Judgments were reviewed and grouped into 10 Dispute Scenarios that contain one or more judgments with the same OPCA litigant or litigants. These disputes were then reviewed for patterns in their subject matter, the OPCA strategies employed, and the characteristics of the litigants themselves.

In each case, an attempt was made to obtain more information on the involved parties via a search for other court activities by the OPCA litigant, participation in online OPCA forums, and Internet social networking activities. This was successful for nine of the 10 OPCA litigants reviewed.

That process identified some litigants whose names had been "anonymized" in reported judgments, typically by replacing a person's name with initials. This article does not report certain details where that additional information may breach legislation that mandates publication bans, or where the parties to family litigation were "anonymized" by the court or a judgment reporter.

The small number of OPCA Inter-Partner Dispute Judgments and Dispute Scenarios precluded meaningful statistical evaluation. ${ }^{70}$ Correlations between litigation and litigant characteristics were therefore only evaluated in a qualitative sense.

\section{OPCA INTER-PARTNER DISPUTES}

The OPCA Inter-Partner Dispute Judgments were divided into a number of subtypes that indicate, generally, the issues in which OPCA activities or affiliation were a factor. In most instances, this was fairly straight forward: a single dominant subject drove the dispute.

\section{A. ChILd Custody}

Three OPCA Inter-Partner Dispute Judgments involved competing claims between parents over child custody and access. ANB reports an OPCA lawsuit concerning control of children where ANB, a father, sued government actors and the mother, sought damages, and claimed 
ownership of the children. ${ }^{71}$ This decision was not included in this category because the primary conflict focused on the child apprehension by state actors, not an inter-parent dispute.

\section{Allan James Curle}

Allan James Curle has employed OPCA concepts in a number of contexts, including family subject disputes. Curle's litigation is unusual both in its variety and forms, and also by the range of material available. Curle has drawn the attention of the Quatloos! Internet forum, a community of hobbyist OPCA analysts and critics who investigate and document OPCA activities worldwide. ${ }^{72}$ The Quatloos! commentators recovered and published a collection of Curle's litigation materials and unreported judgments. ${ }^{73}$ This provides an unusually rich information pool to evaluate Curle's activities and arguments.

Curle's OPCA activities span at least a decade. Curle and other directors of a Thunder Bay engineering corporation attempted to apply Paradigm Education Group Detaxer theories to avoid income tax from 2006 onward. ${ }^{74}$ In 2014, Curle was convicted of tax evasion and conspiracy to commit tax evasion, and received a 14 month jail sentence. ${ }^{75}$ Other known illegal activity by Curle includes non-compliance with motor vehicle licence obligations ${ }^{76}$ and failure to cooperate with a peace officer. ${ }^{77}$ Curle has engaged in OPCA-based attack litigation against his "enemies," such as an unsuccessful civil action and collateral attack against the peace officer involved in his motor vehicle offence scenario. ${ }^{78}$ This misconduct, and Curle's litigation approaches, are an attempt by him to avoid what is known in the OPCA community as "joinder": being subject to state and court authority because of a (fictitious) contract that results from cooperating with state processes and legislation. ${ }^{79}$ Naturally, Curle's attempts to evade "joinder" had no effect, which not only left Curle subject to court and state authority, but, as indicated in Curle, required he follow normal litigation processes. ${ }^{80}$

ANB, supra note 41.

See online: Quatloos! <www.quatloos.com/Q-Forum/>. Quatloos! is a website that tracks, documents, and debunks online scam activity. This often tongue-in-cheek forum is identified in Meads, supra note 3 at para 655 as a useful resource for study of OPCA phenomena. Its members include recognized experts in the Sovereign Citizen and tax protestor movements, such as JJ MacNab, Bernard J Sussman, and Daniel B Evans. While it initially addressed US OPCA phenomena, Quatloos! now has contributors from many Commonwealth countries, including Canada. At present, the Quatloos! forum represents the best public information and news resource for this subject domain.

Burnaby49, “Allan James: Curle - A New Dean Clifford Arising?” (17 June 2014), Quatloos!, online: $<$ www.quatloos.com/Q-Forum/viewtopic.php? $\mathrm{f}=48 \& \mathrm{t}=10060 \& \mathrm{p}=201010 \&$ hilit=Curle\#p201010 $>$.

See Netolitzky, "History of the OPCA," supra note 2 at 622-24; Canada Revenue Agency, News Release, "Directors Fined and Sentenced for Tax Evasion"(16 June 2014), online: <www.marketwired. com/press-release/directors-fined-and-sentenced-for-tax-evasion-1920959>.

Canada Revenue Agency, ibid.

$R v$ Curle, 2015 ONSC 1999, 2015 ONSC 1999 (CanLII) at para 3. This is stereotypic Freeman-on-theLand misconduct, often called "travelling," as OPCA affiliates distinguish between their "travelling" activities versus commercial "driving." See note 187 , below.

$R \vee$ Curle, ibid.

Curle v Given (5 December 2013), Thunder Bay CV-13-0277 (Ont Sup Ct J).

This position is explicit in $R v$ Curle, supra note 76 at para 5. Curle's written submissions in this action have been published by Quatloos and provide a detailed explanation of Curle's current pseudolegal concepts. See note 95, below.

$R \vee$ Curle, ibid at paras 7-8. 
Curle's first documented OPCA judgment is a highly unusual child custody and access dispute with a former common law spouse, Deanna Lowe, and her parents. ${ }^{81}$ Lowe became pregnant, but moved away and kept their child secret. Curle, "a natural person," then sued Lowe and her parents in tort, arguing deceit, intentional interference, unjust enrichment, breach of statutory duty, and demanded damages for loss of "solace, society, companionship and services of the child." 82 Curle's arguments were clearly intended to circumvent a general legal principle established in the Frame v. Smith Supreme Court of Canada decision: that in family law disputes, tort remedies have been displaced by a comprehensive legislative scheme. ${ }^{83}$ Justice Pierce struck out Curle's lawsuit; Curle's custody claim would instead be addressed in a trial scheduled later in $2004 .{ }^{84}$

Further developments in the Curle and Lowe dispute are summarized in a 2014 judgment which declared Curle a vexatious litigant. ${ }^{85}$ Curle unsuccessfully made an unreported appeal of the decision to strike out his tort action against Lowe. Curle was found in contempt of court in the parallel conventional custody action when he refused to produce income tax returns on the grounds that this "violated his rights as a natural person." ${ }^{86}$ Curle's claim for child custody was struck out, and instead he was ordered to pay Lowe child support and costs. In 2011, Curle made a lump sum support payment, but did not pay the costs ordered. ${ }^{87}$

Curle subsequently married and had three more children. In 2011, his wife Juanita Curle sued for divorce, custody, and child support. This litigation is also summarized as part of the 2014 Curle v. Curle vexatious litigant analysis. ${ }^{88}$ Curle once more refused to provide disclosure, ignored child support orders, and did not pay cost awards or orders for security for costs. He attempted to intervene as a separate party in the divorce action, arguing he, "Allan James of the Curle Family," was distinct and separate from the divorce action defendant "Allan James Curle" (in other words, his "Strawman"). ${ }^{89}$

When the intervention application was rejected, Curle initiated a separate collateral attack lawsuit that led to the reported Curle v. Curle vexatious litigation decision. Curle argued:

- his civil marriage was a nullity because of the "Strawman" fraud perpetuated by the state ${ }^{90}$

- he is only subject to common law and international law (International Covenant on Civil and Political Rights; the Universal Declaration of Human Rights; and the Vienna Declaration and Programme of Action); ${ }^{91}$

Curle v Lowe (2004), 10 RFL (6th) 327 (Ont Sup Ct J).

Ibid at para 1.

[1987] 2 SCR 99 at 112.

Curle v Lowe, supra note 81 at para 5.

Curle v Curle, 2014 ONSC 1077, 2014 ONSC 1077 (CanLII) at para 24.

Ibid.

Ibid.

Ibid.

Ibid.

Ibid at para 8 .

Ibid at para 6 . 
- Bouvier's 1856 Maxims of Law is the binding legal authority; ${ }^{92}$ and

- that the disputed children were Curle's property since he had not waived his "full title (legal and equitable)" rights to his children. ${ }^{93}$

Unsurprisingly, Justice Pierce struck out Curle's lawsuit and declared him a vexatious litigant. Curle was subsequently the target of state-mediated child support collection litigation that led to his incarceration for nonpayment. ${ }^{94}$

Curle's recent pseudolegal theories are detailed in his written submissions in several matters: $:^{95}$

- $\quad$ he self-identifies as a Christian who solely follows the Bible, is prohibited from any association with his "person" (a.k.a. his "Strawman"), and therefore is exempt from legislation;

- he has never consented to have or be linked to a "person" or "creature of statute," nor has he contracted with the state;

- he can reject a "creature of statute" under international law and the Constitution of Canada;

- $\quad$ state authority interferes with his religious and fundamental rights and freedoms;

- the Queen is in breach of her Coronation Oath by not enforcing Biblical law as supreme;

- Statutes add to God's Laws, which is forbidden by the Bible. The "person" is a Biblically prohibited "graven image",;

- God will punish him if he accepts having a "person" and follows legislation;

- Acting via the "creature of statute" is "necromancy" and offends the Biblical prohibition against witchcraft. ${ }^{97}$ 99; Vicenc Feliu, "Meeting the Information Needs of Constitutionalist Patrons: A Guide for Reference Librarians" (2006) 25:2 \& 3 Leg Ref Serv Q 89, concerning Bouvier's law dictionary.

93 Curle $v$ Curle, ibid at para 9.

$94 \quad$ Family Responsibility Office v Curle (13 July 2015), FO-13-0287-E001 (Ont Ct J); Family Responsibility Office v Curle (18 April 2017), FO-13-0287-E001 (Ont Ct J).

95 Quatloos! has published Curle's arguments for his unsuccessful judicial review of his criminal convictions and his proposed constitutional attack on child support legislation. See online: Mediafire $<$ www.mediafire.com/view/im33dx1vla0ml3f/Curle_-_CR-15-0019-MO_affidavit_for_judicial review_of_criminal_convictions.pdf $>$; $<$ www.mediafire.com/view/1eujxm9b̄elvlbv/Curle_-_CV-15273 proposed Charter application.pdf $>$.

96 This is derive from certain translations of Exodus 20:4.

See supra note 95. 
These beliefs are an interesting amalgam of OPCA sources, so it seems likely that Curle does not follow a particular guru, but instead has assembled his own unique matrix of pseudolaw. ${ }^{98}$

Family-related matters are not the only theatre for conflict between Curle and his former wife. Both are opposing parties in an ongoing vigorous dispute for control of the Norall Group engineering companies, operated by Curle and two partners (Bruce Johnson and Carl Gustafson), and co-owned by their wives. ${ }^{99}$ This litigation is "conventional" as opposed to OPCA-driven. Curle and his fellow plaintiffs are represented by a lawyer. The Norall Group dispute does, however, have an OPCA facet: Curle, Johnson, and Gustafson were all prosecuted as participants in a Paradigm Education Group Detaxer scheme; Gustafson pled guilty, while the others were convicted. ${ }^{100}$

Though no social media presence was identified for Curle, his court history and documents provide a strong basis to develop a profile of this individual. While Curle is described as polite and organized in court, he clearly exhibits strong animosity towards government authority and those he considers have wronged him. This obsession has ruined his professional life and finances.

Curle is an unusual OPCA litigant. His understanding of actual law and principles is atypically sophisticated, as illustrated by his arguments in Curle v. Lowe. He is, nevertheless, fully embedded in the OPCAsphere. His OPCA affiliation stretches back over a decade. He is undeterred by incarceration. Curle's use of a lawyer in the corporation control dispute suggests Curle takes a very formal approach to OPCA versus conventional litigation, and uses the latter alternative where that is consistent with the basis of a legal relationship. Put another way, in Curle v. Lowe, Curle v. Curle, and R. v. Curle, he rejected being subject to legislation, and therefore advanced OPCA strategies. The business control dispute did not

OPCA gurus often borrow from one another, so it is rare that a particular motif can be uniquely associated with a specific source. That said, it is likely that Curle has been influenced by David Kevin Lindsay's Coronation Oath concepts (see Netolitzky, "History of OPCA," supra note 2 at 620-21), and Curle's references to international law and treaties suggests involvement with websites such as "The Place to Think It Through," online: <www.eternallyaware.com> and "Using Our Intrinsic Rights," online: $<w w w . i n t r i n s i c f r e e d o m s . c o m>$. Curle's extensive reference to specific Bible passages and the invocation of "necromancy" strongly suggests Curle has received instruction from a newer Ontario guru, "Marcus" (actual name Wilfred John Emonts, "Servant King," online: <servantking.info>). Emonts' history is colourful; he is an expert falconer turned marijuana grower (see "Whatever Happened to the 'Falconry Centre'?" online: <https://web.archive.org/web/20161004165303/http://houseofemonts.info/>; Alliston Herald, "Major Drug Bust at Falconry Centre," Simcoe.com (5 July 2012), online: <https:// www.simcoe.com/news-story/2027692-major-drug-bust-at-falconry-centre/>). The Coronation Oath and Biblical literalist aspects of Curle's material might also suggest a link to the Church of the Ecumenical Redemption International (CERI) and its guru, "minister" Edward Belanger (see Netolitzky, "History of the OPCA," supra note 2 at 627-28), however, CERI materials are notoriously amateurish and haphazard. Curle's sophisticated court documents instead suggest a Detaxer connection. Curle v Gustafson, 2013 ONSC 2463, 2013 ONSC 2463 (CanLII); Curle v Gustafson, 2013 ONSC 4139, 2013 ONSC 4139 (CanLII); Curle v Gustafson, 2013 ONSC 4769, 2013 ONSC 4769 (CanLII); Curle v Gustafson, 2013 ONSC 7287, 2013 ONSC 7287 (CanLII); Curle v Gustafson, 2014 ONSC 5865, 2014 ONSC 5865 (CanLII); Curle v Gustafson, 2014 ONSC 6639, 2014 ONSC 6639 (CanLII); Curle v Gustafson, 2015 ONSC 884, 2015 ONSC 884 (CanLII); Curle v Gustafson, 2015 ONSC 2127, 2015 ONSC 2127 (CanLII); Gustafson v Johnson, 2016 ONSC 2084, 2016 ONSC 2084 (CanLII); Gustafson v Johnson, 2016 ONSC 3358, 2016 ONSC 3358 (CanLII); Gustafson v Johnson, 2016 ONCA 972, 2016 ONCA 972 (CanLII).

100 Canada Revenue Agency, News Release, "Professional Engineer Fined and Sentenced to House Arrest for Tax Evasion" (30 October 2013), online: <www.marketwired.com/press-release/professionalengineer-fined-and-sentenced-to-house-arrest-for-tax-evasion-1846692>. 
(at least directly) involve legislation or state authority, so Curle used "conventional" litigation approaches and a lawyer.

\section{JASON PENNEY}

Jason Penney and Angela Tufts, an unmarried couple with a single child, separated and entered into a shared custody arrangement. Applications to revise custody and access led to three reported decisions. ${ }^{101}$ Inter-parent conflict escalated, the mother became the primary custodial parent, and Penney was ordered to pay child support. ${ }^{102}$ While Penney was a good father, his interactions with his ex-partner were difficult and aggressive, and that hostility interfered with the child's well-being. Penney made unsuccessful self-represented appeals where the Court rejected new evidence as inadmissible, refused to permit a late appeal, ${ }^{103}$ and observed that Penney had failed to understand that the conflict with his ex-partner cannot trump the best interests of his child. ${ }^{104}$ The current custody arrangement was working and appeared to be in the child's best interests. ${ }^{105}$ The Court rejected Penney's application for reduced child support; he argued he was a self-employed part-time fisherman restricted by a back injury. ${ }^{106}$

The Penney v. Tufts proceedings are an unfortunate, though unremarkable, family dispute scenario. OPCA arguments only appear in the late appeal decision. Penney challenged the jurisdiction of the Court, "said he was not 'Mr. Penney," but instead was "“Jason' and that Mr. Penney did not exist." "107 Justice Farrar observed that this behaviour suggests affiliation with the Freemen-on-the-Land or related movements who engage in strategies "to prolong litigation and to ignore [courts'] rules of procedure." 108 Accordingly, Penney had not appealed in good faith. ${ }^{109}$ This language clearly indicates Penney was invoking the double or split person "Strawman" concept in an attempt to dispute court jurisdiction.

Penney's Internet social media accounts were identified. They disclosed no unusual beliefs or affiliations, particularly those stereotypic to the OPCAsphere. It appears Penney only flirted with OPCA ideas and then abandoned them as ineffective.

\section{S.M.}

The one reported S.B. v. S.M. judgment was the latest development in an almost decadelong divorce proceeding that involved a male child. ${ }^{110}$ The parents separated in 2005 and formally divorced in 2007. ${ }^{111}$ The father, S.M., paid child support and generally sought

Penney $v$ Tufts, 2013 NSCA 126, 336 NSR (2d) 95 [Penney 1]; Penney $v$ Tufts, 2014 NSCA 38, 343 NSR (2d) 378 [Penney 2]; Penney v Tufts, 2014 NSSC 411, 352 NSR (2d) 272 [Penney 3]. Penney 1 , ibid at paras 3,12 .

Penney 2, supra note 101 at paras 19-26.

Penney 1 , supra note 101 at paras $7,13,15-18$.

Penney 2, supra note 101 at para 30.

Penney 3, supra note 101 at paras 2-4, 15-19. See also Penney 3, ibid at paras 5-8 where Justice Lynch rejected Penney's argument that she recuse herself for having previously ruled against Penney in other proceedings.

Penney 2, supra note 101 at para 24.

Ibid at para 25.

Ibid at paras 25-26.

2014 BCSC 2105, 2014 BCSC 2105 (CanLII).

Ibid at para 4. 
additional access. ${ }^{112}$ Justice Blok's detailed review of the facts and history of this matter makes it obvious that the couple had serious conflict issues. S.M. argued S.B. attempted to alienate him and his son. ${ }^{113}$ S.B., in turn, suggested that S.M. tried to undermine her parentchild relationship. ${ }^{114}$ Expert psychiatric evidence indicated the child was clearly affected by this conflict. ${ }^{115}$

S.M.'s OPCA activities were part of the file history. Shortly after the couple separated, S.M. adopted what Justice Blok called "behaviours associated with the 'freeman' or 'sovereign citizen' movements," 116 and "repeatedly questioned the court's jurisdiction."117 This continued for 16 months. ${ }^{118}$ S.M. later acknowledged this was "bad advice" and "questionable," noting that he was embarrassed over the episode: "In my defence, I was broke, garnisheed, bullied and felt backed into a corner." 119 S.B. perceived this period as one of high risk: S.M. was "very combative and aggressive"; ${ }^{120}$ his documents seemed "irrational." 121

Justice Blok rejected the parental alienation allegation. While both parents loved their son, they had incompatible parenting styles. ${ }^{122}$ A major contributing factor was S.M.'s hostile, aggressive, and unconstructive approach to his ex-wife. Justice Blok saw the "freeman" phase where S.M.'s communications "were overtly hostile as well as irrational" as simply a severe manifestation of this aspect of S.M.'s personality. ${ }^{123}$ S.M.'s access was reduced, guardianship would follow the "Master Joyce" model, and restrictions on speaking about the other parent continued. ${ }^{124}$ S.M. was ordered to pay retroactive child support, but not on the basis that he had been dishonest in relation to his income. ${ }^{125}$

S.M. was identified, but that did not provide any additional details concerning his 2006-2008 OPCA activities. An undisclosed aspect of his divorce litigation is that in 2006, S.M. filed a countersuit against S.B., which was apparently not pursued after the initial filing. The substance of that action was not investigated.

\title{
B. Property Disputes, AND ChILd AND SPOUSAL SUPPORT
}

Four identified Dispute Scenarios involve property and support issues. While all but one (Hill v. Hill ${ }^{126}$ ) of these disputes involved children, child custody, or access, these subjects were either a non-issue between the parents, or not the target of OPCA strategies. Adkina $v$.

\author{
Ibid at paras 8-19. \\ Ibid at para 29. \\ Ibid at para 54 . \\ Ibid at para 109. \\ Ibid at para 35 . \\ Ibid at para 58 . \\ Ibid at para 106. \\ Ibid at para 35. \\ Ibid at para 58 . \\ Ibid at paras 58, 106 . \\ Ibid at paras 117-18. \\ Ibid at para 106. \\ Ibid at paras 122-24. \\ Ibid at paras 162, 167. \\ 2008 SKQB 11, 306 Sask R 259 [Hill].
}


Badalov ${ }^{127}$ may possibly belong in this category, but this author was unable to verify whether the unusual arguments advanced in that dispute derive from an OPCA source, or are only coincidentally similar to certain religion-based OPCA schemes.

\section{DENNIS LARRY MEADS}

Commentary on Meads has paid comparatively little attention to the actual dispute between Crystal Lynne Meads and Dennis Larry Meads that brought them to court in the first place. The couple married in 1980 and had six children. Dennis Meads worked for an oil patch business in a professional capacity. The Meads separated in 2010. Interim child and spousal support was ordered in March of 2011. ${ }^{128}$ Dennis Meads generally honoured his court-ordered obligations. ${ }^{129}$ At this point the litigation developed an OPCA character. Dennis Meads deployed unorthodox documents that appointed a clerk of the court as his fiduciary, and directed a "Motion For An Order To Show Cause" to counsel for Crystal Meads. ${ }^{130}$

Crystal Meads applied for case management. This led to a hearing on 8 June 2012 where Dennis Meads argued:

- $\quad$ he was in court, not his "Strawman"; 131

- he was subject to God's law, and not the admiralty law practiced by the Court; ${ }^{132}$

- Crystal Meads had engaged in adultery, and that breached ("annulled") the God's Law marriage contract; ${ }^{133}$

- $\quad$ he should pay child and spousal support, including assisting a daughter now attending post-secondary education, but denied that he had a legal obligation to do so ${ }^{134}$

- $\quad$ his "Strawman," which he described as "a corporate identity," was associated with a large sum of money, and those funds should serve as the source of his child and spousal support payments, ${ }^{135}$

- $\quad$ he provided various documents to permit access to the "Strawman" funds; ${ }^{136}$

- Crystal Meads had received her fair share of the matrimonial property: 50 percent of "the marriage corporate entity," his silver bullion, and $\$ 250,000.00$ from a joint bank account; ${ }^{137}$ and

2013 ONSC 6067, 2013 ONSC 6067 (CanLII).

Meads, supra note 3 at para 10 .

Ibid. The notable exception was disclosure issues: see ibid at para 682 .

Ibid at paras 11,707 .

Ibid at para 13 .

Ibid at paras 16, 22, 24, 33.

Ibid at paras 16,705 .

Ibid at paras 17, 20.

Ibid at paras 15,17 .

Ibid at para 17.

Ibid at paras 18, 21. 
- Crystal Meads had retrained, was in a new relationship, and had her own home. ${ }^{138}$

Dennis Meads did not want to be "entic[ed] into contract" or "enticed into slavery"; ${ }^{139}$ he just wanted his divorce, and appointed Associate Chief Justice Rooke as his fiduciary to obtain that result per God's law, the "Maximus of Law." ${ }^{140}$ He acknowledged an obligation to provide outstanding tax return information. ${ }^{141}$ Dennis Meads explicitly sought a courtordered divorce to end these proceedings. ${ }^{142}$

Meads details Dennis Meads' OPCA documents, so it is sufficient to simply summarize their scheme. The documents structure a contract between "Dennis-Larry: Meads" (flesh and blood) and "DENNIS LARRY MEADS" (his "Strawman") where the "Strawman" receives all debts and liabilities, and the physical Dennis Meads has all assets and benefits. Dennis Meads instructed the Court to use the attached birth certificate and US and Canadian property registrations to order payment of his matrimonial, child support, and spousal support obligations from a $\$ 100$ billion "public treasury" held by the Bank of Canada. In brief, this is an "A4V" money for nothing strategy. ${ }^{143}$

Dennis Meads' complaint at the 8 June 2012 hearing was that he had instructed Crystal Meads' counsel to implement the "A4V" scheme, but she had not done so. ${ }^{144}$ Dennis Meads resisted attempts to "contract" by the Court, Crystal Meads, and her counsel. That would trigger "joinder" and make Dennis Meads (flesh and blood) subject to "admiralty law" (a.k.a. Canadian and Alberta family law legislation). ${ }^{145}$

Subsequent to the release of Meads, Dennis Meads obtained counsel. The divorce proceeding continued in a conventional manner. Meads generally discharged his courtordered obligations, and filed the outstanding income tax returns.

This author has personal knowledge of this litigation. Further attempts to profile Dennis Meads were generally unsuccessful. Dennis Meads was apparently attempting to implement a US Sovereign Citizen scheme. The source guru and Meads' OPCA social community, if any, remain unidentified.

\section{J.M.}

C.C. and J.M. began cohabiting in 2000 . They had one child, T.M. The mother, C.C., had several children from a previous relationship, and had allegedly experienced one sexual abuse incident by J.M. ${ }^{146}$ The Saskatchewan Ministry of Social Services became involved, the relationship deteriorated, and C.C. left their home in $2006 .{ }^{147}$ Litigation followed, and the only reported decision in this dispute was to arrange child custody, as well as spousal and

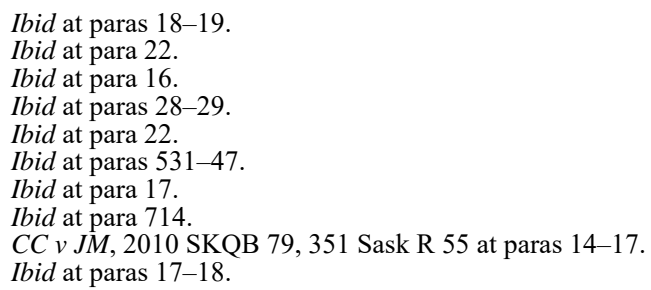


child support. ${ }^{148}$ J.M. appeared at the hearing but refused to enter the body of the courtroom. He cited the Bible and filed unorthodox documentation, such as "bonds" signed with a thumbprint or blood. ${ }^{149} \mathrm{He}$ was disruptive and disrespectful, and at one point he was removed from the courtroom. ${ }^{150}$ J.M. had initially paid child and spousal support, but stopped after C.C. cashed a cheque annotated with text which stated that cashing the cheque meant C.C. had agreed to a contract that ended J.M.'s obligations. ${ }^{151}$

C.C. received sole custody of T.M. The Court ordered division of matrimonial property, ongoing child and spousal support, and a structure for J.M. to access the child. J.M. was reportedly uncooperative, domineering, abusive, and apparently disinterested in T.M. and his needs. ${ }^{152}$ C.C. obtained sole custody because of J.M.'s OPCA beliefs and claims to be outside legal control. ${ }^{153}$

J.M. was identified. He has a lengthy history of OPCA affiliation and activity. In 2013, J.M. and his company were convicted of tax evasion and fined over $\$ 250,000$, with J.M. sentenced to 14 months incarceration. ${ }^{154}$ J.M. was involved with the Paradigm Education Group Detaxer ring, ${ }^{155}$ but his court documents indicate he also used Sovereign Citizen concepts.

\section{R.L.L.}

A separating couple, G.G.D. and R.L.L., conducted a summary trial to impute R.L.L.'s income, set child support, and identify and divide the family property. ${ }^{156}$ R.L.L., the father, advanced no evidence. He restricted his arguments to claims that he was outside court authority because he is a "free man," and referenced the Criminal Code, section 39, and the Magna Carta. ${ }^{157}$ The only written decision in this dispute calculated costs, post-trial.

While R.L.L. is clearly an OPCA litigant, the limited evidence available restricts analysis of his pseudolegal strategy. The Criminal Code argument suggests Freeman-on-the-Land affiliation. ${ }^{158}$ Both G.G.D. and R.L.L. were identified. R.L.L. exhibits no unusual interests or litigation activity. G.G.D. shows some moderate personal interests common in Freeman communities.

\footnotetext{
Ibid at para 17 .

Ibid at para 10 .

Ibid at paras 8-9.

Ibid at paras 11-12.

Ibid at paras $18,26-27$.

Ibid at paras 30,33 .

Note that some of the claims in this paragraph lack citation to protect the identity of J.M.

Netolitzky, "History of the OPCA," supra note 2 at 622-24.

GGD v RLL, 2004 BCSC 580, 2004 BCSC 580 (CanLII) at paras 1-2. The docket number on the reported judgment does not appear to be correct.

Ibid at para 4 .

Criminal Code, supra note 38, s 39(1) was repealed on 11 March 2013. This section stated that anyone who is "in peaceable possession" of property "under a claim of right" does not face sanction for using necessary force to defend that property. Freeman guru Robert Menard interpreted this provision to mean that if one created a foisted unilateral agreement document called a "Claim of Right," then whatever is in that document, combined with section 39(1), provides a total defence to criminal charges: Menard, Lawful Excuse, supra note 33 at 28-31, 39, 48-57, 69, 71, 117-19.
} 


\section{HELEN IRENE HILL}

The matrimonial property dispute between Gerald Elmer Hill and his ex-wife, Helen Irene Hill, is a rare example of a property dispute between two spouses that involves an OPCA aspect. The Hills were married in 1967 and separated in 1990. Their divorce was formalized in 2005 after three separation property agreements $(1993,1996,1999)$ were made with legal advice. ${ }^{159}$ Helen Hill, in 2008, sought to reopen those agreements and obtain interim spousal support. ${ }^{160}$ She argued, largely without evidence, that she had made significant contributions to Gerald Hill's many residential rental properties. ${ }^{161}$

The first reported judgment in this dispute concerned whether notorious Detaxer guru David Kevin Lindsay could represent Helen Hill as her agent. The Court indicates Lindsay had filed hundreds of pages of materials that "is very difficult to comprehend" and is "entirely incorrect legally." "T2 This alone was a basis to reject Lindsay. However, Justice McMurtry continued to review how Lindsay had an established reputation in British Columbia and Manitoba as a vexatious litigant. He was therefore not an appropriate agent. ${ }^{163}$ The judgment does not detail Lindsay's arguments, and Lindsay's scheme is not obvious. Meaningful analysis of this Dispute Scenario is therefore difficult. Helen Hill, with legal counsel, later unsuccessfully resisted Gerald Hill's application to vacate her certificate of lis pendens on his properties. ${ }^{164}$ This application shows no unorthodox aspects. The remainder of this dispute is not apparently reported.

Helen Hill was located online. She died on 12 January 2015. ${ }^{165}$ Hill was a real estate agent from the date of her separation. ${ }^{166}$ Her social networking website shows interest in unconventional medicines, organic foods and food contamination, and alternative and New Age topics. ${ }^{167}$ Unusually, she does not exhibit the anti-government foci that are stereotypic of those deeply embedded in the OPCAsphere. Hill's OPCA affiliations continued after her collaboration with Lindsay. In 2014, she expressed enthusiasm for South African OPCA guru Michael Tellinger. ${ }^{168}$

\section{OPCA AfFiliation AS A Negative INDiCIUM}

Several reported judgments in the sample group are not OPCA litigation, at least not in the usual sense. Instead, these decisions report a conflict between non-OPCA and OPCA parents, where OPCA affiliation was raised as relevant to parental competence and fitness. Two of the three identified cases are strictly a parent versus parent custody dispute, but the third example, A.B., also involved property and support issues. The A.B. dispute is treated

\footnotetext{
Hill, supra note 126 at paras $1-3$.

Ibid at paras 3,20 .

Ibid at paras 10-14, 31-32.

Ibid at para 26.

Ibid at paras 27-30.

Hill v Hill, 2008 SKQB 58, 312 Sask R 155.

See Speers Funeral Chapel, "Obiturary of Helen Hill" (12 January 2015), online: <www.speersfuneral chapel.com/tribute/details/5454/Helen-Hill/obituary.html\#tribute-start>.

Hill's real estate agent profile could originally be found at Homes.com, online: $<$ www.homes.com/realestate-agents/helen-hill/id-11481336/>, but appears to have been removed just prior to publication of this article. 
as a child custody scenario since, by the time of the divorce judgment, the matrimonial property assets had been largely dissipated and A.B.'s income was much reduced.

1. G.J.

This family law scenario is well documented in a single 2013 British Columbia Provincial Court judgment. ${ }^{169}$ G.J., a German citizen, in 2002 fathered a daughter with a Canadian nurse during a transatlantic relationship. S.H. subsequently sponsored G.J.'s immigration to Canada. A joint custody order with S.H. as the primary caregiver was put in place after the relationship decayed in 2005 and G.J. moved out. ${ }^{170}$ There were some disputes concerning the duration and timing of the child's visits with G.J., who consistently concealed the location of his residence. ${ }^{171}$ Inter-parental conflict escalated, and S.H. was awarded interim sole custody in $2012 .{ }^{172} \mathrm{G} . J$. continued to access his daughter, with that access structured to support extracurricular activities. ${ }^{173}$ In 2012, retroactive child support was ordered (2010 2012) on an imputed income of $\$ 45,760$; however, G.J. refused to pay child support, and said he did not think he had to pay unless he had 50 percent access to his daughter. ${ }^{174}$

The reported decision has two foci: a new access structure for G.J., and the mother's concerns regarding G.J.'s OPCA beliefs and social affiliations. S.H. sought an order to block the daughter's potential exposure to G.J.'s OPCA mentor, "R.D. from the House of H.," and to OPCA concepts and anti-government perspectives in general. ${ }^{175}$

G.J. had extensive training and experience as a mechanic and in technical domains, but he made no use of those skills in Canada. ${ }^{176}$ G.J. had vague explanations of working in television, movies, and news media, but this work was either unpaid or for barter. ${ }^{177}$ G.J. received a Workers' Compensation Board payment of $\$ 650.00$ per month as a consequence of a 2008 assault. ${ }^{178}$ The Court concluded G.J. was underemployed and had ignored his parental obligations. ${ }^{179}$ "R.D. from the House of H." and G.J. testified about their pseudolegal beliefs, which were entirely typical OPCA concepts that deny court and state authority, motor vehicle legislation requirements, and income tax obligations. ${ }^{180}$

Judge Dyer concluded that G.J. was a caring parent with good intentions toward his daughter, but his OPCA beliefs and social contacts were not appropriate. ${ }^{181}$ G.J. was prohibited from discussing or advocating OPCA concepts, and from allowing his daughter

\footnotetext{
SH v GJ, 2013 BCPC 242, 2013 BCPC 242 (CanLII).

Ibid at paras 2-6.

Ibid at paras 7-16, 25, 73-75, 120.

Ibid at para 18 .

Ibid at para 23

Ibid at paras 20-21.

Ibid at paras $43,80-103$.

Ibid at paras 51-53.

Ibid at paras 54-56.

Ibid at para 70. Reliance on welfare, social assistance programs, and pensions is not uncommon among OPCA litigants, including gurus.

Ibid at paras $59,61,63,70$.

Ibid at paras 80-103. While both distanced themselves from the Freeman-on-the-Land label, review of their in-court activities and other data makes it obvious that both are Freemen. This evasive response to Freeman affiliation is increasingly common, likely due to the public's highly negative post-2012 response to the Freeman movement. Ibid at para 132 .
} 
to be in the presence of "R.D. from the House of H." 182 The judgment also provides a detailed structure and schedule for G.J. to access his daughter and facilitate their generally positive relationship.

G.J. and "R.D. from the House of H." were identified. Both are closely associated with the local area OPCA community and actively support their social group peers, including illegal and criminal OPCA activities. They exhibit leftist, ecologically focused, unorthodox, and conspiracy theory interests that are stereotypic of the Freeman-on-the-Land community. G.J.'s online presence matches the Court's evaluation of G.J.'s rather "shiftless" existence of temporary residences and notational, cause-oriented activities. ${ }^{183}$

An alarming factor that was not apparently fully in evidence at the 2013 access and custody hearing is that both G.J. and "R.D. from the House of H." were involved in multiple criminal proceedings that resulted from them acting on their OPCA beliefs. ${ }^{184}$ In March 2013, G.J. was found guilty of driving without a licence in 2011 , and was fined. ${ }^{185} \mathrm{He}$ faced further charges for resisting and assaulting a peace officer, driving while impaired, and failing to provide a breath sample. ${ }^{186}$ These offences are consistent with a commonly observed pattern of illegal OPCA activities, where an OPCA affiliate refuses to comply with motor vehicle legislation because the OPCA affiliate is not "driving," but only "travelling." 187

"R.D. from the House of H." is an electrician by trade. ${ }^{188}$ In June 2014, he was found guilty of resisting or obstructing a peace officer, flight from a peace officer, dangerous operation of a motor vehicle, breach of recognizance, driving while impaired, refusing to provide a breath sample, driving an uninsured vehicle, and driving without a licence. ${ }^{189}$ As a result, he was fined, jailed, and prohibited from driving for one year. This flowed from "travelling" in October 2012 and December 2013, as well as subsequent court order breaches. H. repeatedly breached his driving suspension in December 2014, and is now the subject of multiple arrest warrants for his failure to attend court. He has been incarcerated for contempt of court. H. has also recorded many videos advocating OPCA concepts and expressing stereotypic OPCAsphere perspectives and conspiracies. G.J., as a "reporter," has commented on H.'s criminal proceedings, and published standard OPCAsphere "editorials"

182 Ibid at paras $156-65$.

183 This is not an atypical Freeman lifestyle.

184 Ibid at paras 27,57 . This account mentions criminal proceedings against G.J. which his daughter attended, but indicates that those had been stayed. G.J.'s criminal litigation record does not support this statement, which suggests that G.J. misinformed Judge Dyer as to the state of G.J.'s criminal proceedings.

185 This was pursuant to the Motor Vehicle Act, RSBC 1996, c 318, s 24(1).

186 This was pursuant to the Criminal Code, supra note 38, ss 129(a), 270(1), 253(1), 254(5), respectively. Recent examples of criminal "travelling" judgments include $R$ v Alexander, 2012 BCPC 108, 2012 BCPC 108 (CanLII); Rv Dornn, 2012 MBCA 85, 284 Man R (2d) 36; Viglione c Société de l'assurance automobile du Québec, 2012 QCCS 2742, 2012 QCCS 2742 (CanLII); $R$ v Ainsworth, 2015 ONCJ 98, 2015 ONCJ 98 (CanLII); $R$ v Ainsworth, 2015 ONCJ 99, 2015 ONCJ 99 (CanLII); $R$ v Bydeley, 2012 ONCJ 837, 2012 ONCJ 837 (CanLII); $R v$ Chandler, 2014 ONCJ 709, 2014 ONCJ 709 (CanLII); $R v$ Furqan, 2013 NSCA 55, 2013 NSCA 55 (CanLII); $R v$ Valliere, 2013 ONCJ 158, 2013 ONCJ 158 (CanLII); $R v$ Westover, 2013 ONCJ 472, 49 MVR (6th) 336; $R v$ Hanoski, 2016 ABPC 76, 2016 ABPC 76 (CanLII). Some OPCA gurus teach that "travelling" is mandatory to avoid government authority: see Netolitzky, "Attack on the Legal System," supra note 11 at 174-75. The roadside stops that result from "travelling" are a flashpoint of potential violent conflict.

188 Note that some of the claims in this paragraph lack citation to protect the identity of "R.D. from the House of H."

189 Criminal Code, supra note 38, ss 129, 249.1(1), 249(1)(a), 145, 253(1), 254(5); Motor Vehicle Act, supra note 185 , ss 24(3), 24(1), respectively. 
that denounce judges, police, and the Crown. They (allegedly) lack true authority and operate above the law. Both G.J. and "R.D. from the House of H." are obviously fully immersed in and committed to the OPCAsphere and its perspectives.

\section{T.C.}

M.D.C. and T.C. were a married couple with two young children. Three reported judgments document their divorce and post-divorce custody dispute. ${ }^{190}$ The OPCA aspect to this dispute emerges in the final 2012 decision. The initial decision refused a divorce because the parties had not yet separated for a year, and ordered interim shared custody. ${ }^{191}$ Justice Walsh rejected the mother's allegations that T.C., the father, was a disinterested parent, and concluded that both parents had the childrens' best interests at heart. ${ }^{192}$

In late 2011, M.D.C. applied to vary the custody arrangement. Conflict between the parents had escalated to the point that shared custody was no longer viable. T.C. refused to return the children and complained to child services authorities about child abuse. ${ }^{193}$ The Court preferred the father's evidence, recognized the older child's request to live with his father, and concluded M.D.C. was under stress and that had impeded the inter-parent relationship. ${ }^{194}$ The Court gave T.C. sole custody of the children; M.D.C. had weekend access. $^{195}$

M.D.C. once again applied to vary child custody in September 2012, arguing a change in circumstances: T.C.'s Freeman-on-the-Land beliefs and actions had led to police conflict. T.C.'s driver's licence had been suspended after he refused to pay a traffic ticket; T.C. then lost his truck driver job. ${ }^{196}$ In August 2012, T.C. was stopped by police for driving while suspended, which led to a confrontation with multiple officers where T.C. refused to identify himself, denied police authority, and threatened to fine the officers " $\$ 500.00$ for every hour he was detained and \$1,000 if he was arrested." ${ }^{197}$ T.C. was arrested, his vehicle was towed, and M.D.C. attended the police station to identify him. ${ }^{198}$ A second similar incident occurred four days later. ${ }^{199}$ Both times, the children were present. ${ }^{200}$

T.C. had become obsessed with OPCA concepts several years earlier, and was affiliated with the World Freeman Society of Canada. ${ }^{201}$ In court, T.C. explained aspects of his Freeman beliefs, including that he is only subject to "common law" or "natural law," that

MC v TC, 2010 NBQB 192, 362 NBR (2d) 94 [TC 1]; MDC v TC, 2012 NBQB 4, 2012 NBQB 4 (CanLII) [TC 2]; MC v TC, 2012 NBQB 376, 2012 CarswellNB 730 (WL Can) [TC 3].

TC 1, ibid.

Ibid at para 30

TC 2, supra note 190 at paras 6-9, 14-19.

Ibid at paras 23-24, 35-36, 42.

Ibid at para 44 .

TC 3, supra note 176 at paras 8-9.

Ibid at para 9. T.C. almost certainly had sent authorities some kind of fee schedule (see Meads, supra note 3 at paras 505-23). This is another basis for criminal sanction: see Meads, ibid at para 527; Fearn, supra note 41 at para 199.

TC 3, ibid at paras $9-10$.

Ibid at paras $12-13$.

Ibid at para 13 .

Ibid at paras 10-11. This is the largest currently operating Freeman-on-the-Land organization. See World Freeman Society, online: <worldfreemansociety.org > . Menard self-identifies as its "Director." The World Freeman Society is a commercial source for Menard's books and DVDs. 
statutes are contracts, and that one can opt out of being subject to legislation. ${ }^{202}$ Justice Walsh concluded T.C.'s OPCA affiliation was a change in material circumstances that required the Court to re-evaluate his fitness as a parent, since this illegal belief system could be transmitted to his children. ${ }^{203}$

The mother's employment and domestic circumstances had improved, while the father had lost his job. The inter-parent relationship was now poisonous, with reciprocal allegations made by each parent to the Child Protection Unit. ${ }^{204}$ Justice Walsh concluded the children needed a stable domestic scenario, so the father should remain the custodial parent. T.C. claimed he had not shared his Freeman ideology with the children. ${ }^{205}$ The Court was disappointed with T.C., stressed the need for improved parent to parent communication, and ordered that T.C. engage in no further driving while unauthorized and that T.C. not expose his children to OPCA concepts. ${ }^{206}$

The parties to this litigation were not identified. The available data does not permit a general investigation of T.C.'s beliefs and background, though TC 1 does indicate T.C. had concerns over the health implications of plastics and food. ${ }^{207}$ Unusual health and food concerns are typical in Freeman society.

3. A.B.

A common law couple, A.B. and M.L., married in 2004. Their 2012 divorce resulted in four reported judgments. ${ }^{208}$ The couple had three daughters: two prior to, and one after, their marriage. A.B. and M.L. disputed child custody, support, and matrimonial property division. The parties co-owned a house with their shares set under a joint agreement. ${ }^{209}$

Their relationship deteriorated in 2006 after A.B. lost his seat in Parliament. ${ }^{210}$ This climaxed in 2009 when the parties separated with reciprocal claims of abuse, misconduct, instability, and risks to the children. ${ }^{211}$ Child services and police became involved, and as an interim measure, M.L. became the custodial parent with A.B. having permitted access. ${ }^{212}$ A.B.'s post-Parliament employment further degraded as the divorce dispute escalated. ${ }^{213}$ In 2011, the matrimonial home was targeted for foreclosure after A.B. failed to make mortgage and tax payments. ${ }^{214}$

TC 3, ibid at paras 15-17.

Ibid at paras 19-20.

Ibid at para 30 .

Ibid at paras 44, 46.

Ibid at para 59 .

Supra note 190 at para 3 .

Droit de la famille - 123381, 2012 QCCS 6120, 2012 QCCS 6120 (CanLII) [AB 1]; Droit de la famille - 13334, 2013 QCCA 282, 2013 QCCA 282 (CanLII) [AB 2]; Droit de la famille - 131016, 2013 QCCA 725, 2013 QCCA 725 (CanLII) [AB 3]; Droit de la famille - 132480, 2013 QCCS 4394, 2013 QCCS 4394 (CanLII) [AB 4].

$A B 1$, ibid at paras 19-20.

Ibid at paras $31,33,36,39$.

Ibid at paras $45-55,59,83,137$.

Ibid at paras 57-58, 61, 63-64, 86, 91-92, 96, 101-103.

Ibid at paras 66, 93 .

Ibid at para 107 . 
This is the point at which the OPCA component of this scenario emerged. In 2011, A.B. refused to have his daughter immunized, and wrote in English "Without Prejudice [A B], AUTHORIZED REPRESENTATIVE." 215 A.B. also explained in court that he was going to pay the matrimonial home mortgage and his tax obligations from a US Treasury Board trust account in Washington D.C. that is related to his birth registration "Bond."216 This account allegedly exists as Canada is allegedly bankrupt, but also could serve as a source of funds to pay income tax. A.B.'s manner of signing documents indicated he owned this trust account. Unsurprisingly, A.B.'s attempt to pay his mortgage with a "Private Registered Setoff Bond" was rejected, and the bank took possession of the matrimonial home for courtordered sale. $^{217}$

This was obviously a high-conflict relationship. ${ }^{218}$ Both parents reported an unusual childhood, including sexual activities. A psychologist and a social worker evaluated the parents; neither report was favourable. ${ }^{219}$

Justice Cullen ordered that M.L. retain custody of the children. A.B. had access every other weekend. Justice Cullen criticized both parents for placing their own interests ahead of the children. The open inter-parental conflict had caused the children injury. ${ }^{220}$ A.B.'s OPCA affiliation led the Court to question his mental health. ${ }^{221}$ A.B.'s unpaid child support was cancelled, the family's RRSP's had been consumed, and M.L.'s share of the matrimonial home sale proceeds was defined by the initial agreement between the spouses.

A.B. unsuccessfully appealed in an effort to obtain custody, also alleging bias and error in calculating property division and support. ${ }^{222}$ A.B. now acknowledged his attitude may have caused the trial judge to question his competence, and the Court noted A.B. was different: articulate, calm, and organized. ${ }^{223}$ This implies A.B. had, by this point, abandoned his OPCA concepts. ${ }^{224}$ The final reported decision indicates that the parents had resumed their litigation, and exchanged allegations of vexatious conduct and a tort claim of several hundred thousand dollars. ${ }^{225}$ All applications were denied, and Justice Denis observed: "Tout cela n'a plus de bon sens." 226

A.B.'s mechanism to pay his mortgage and income tax is clearly an "A4V" "money for nothing" scheme. ${ }^{227}$ Briefly, this is a US OPCA concept that the "Strawman" is associated with a secret government-managed bank account. A process called "Redemption" allows the "attached" flesh and blood human to make payments from the secret "Strawman" account. While "Canadianized" variations on "A4V" are known, ${ }^{228}$ A.B. used a US-style form. The

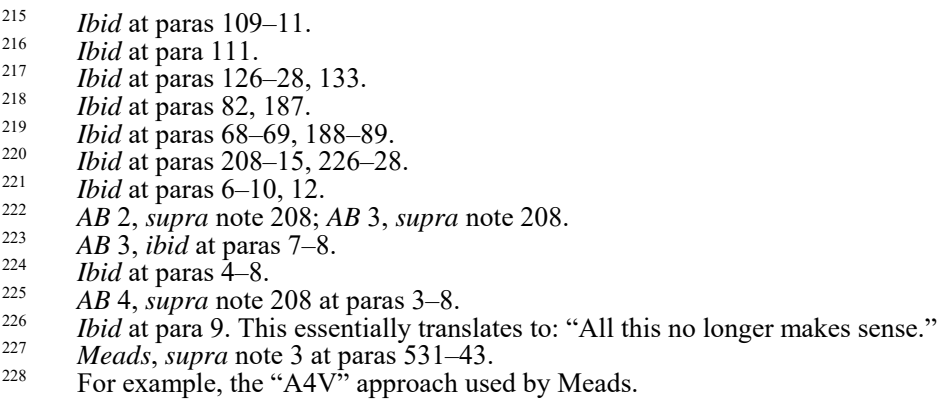


language that described the "A4V" scheme and its timing strongly suggests A.B. followed a yet unidentified "A4V" guru who operated in Quebec during this time period. ${ }^{22}$

The parties were identified. A.B. is litigious: many other legal disputes were located, along with one appeal judgment in his foreclosure action. ${ }^{230}$ Before entering into politics, A.B. was a professional. The only non-OPCA unorthodox belief or affiliation identified for A.B. was the rejected vaccination.

\section{AnAlysis}

OPCA litigation that involves family law subjects is comparatively unusual. Court decisions that report inter-partner conflict in this subject domain represent only a very small fraction (19 of 725) of the OPCA Judgment Dataset.

That said, this judgment "head count" methodology should be viewed with caution. Several factors may skew or distort this data. First, only a small portion of OPCA litigation results in reported decisions. ${ }^{231}$ Instead, most OPCA actions are disposed of in preliminary steps or via oral judgments. Second, the OPCA Judgment Dataset probably overrepresents appellate and superior court litigation. These are forums where a judge is more likely to write, and more decisions are reported because of their potential as legal precedents.

Third, the OPCA Judgment Dataset is almost certainly incomplete. This raises the possibility that the OPCA Judgment Dataset could omit judgments that flow from attempts to apply a specialized family dispute-specific pseudolegal argument, particularly if this hypothetical argument used novel language and motifs not shared by other OPCA schemes. While this possibility cannot be eliminated, this scenario is fairly unlikely. For one, some OPCA litigants engage in different kinds of litigation; for example, attempting to avoid both income tax and criminal sanction. Name-based searches "bridge" these category gaps and may expose cryptic family-specific OPCA litigation schemes. Moreover, OPCA affiliates are enthusiastic scavengers of related pseudolegal and conspiratorial information and, frankly, are gossips. If a Canadian group or guru were to develop unique, family-specific pseudolaw, and then engaged in court litigation, the possibility that such information would remain sequestered and unknown to the OPCAsphere at large is low.

These complicating factors, coupled with the small OPCA Inter-Partner Dispute Judgment sample size, mean that an attempt to analyze this data set in a quantitative sense is premature. Nevertheless, the comparatively low frequency of family law issues in reported OPCA litigation matches the author's personal experience and anecdotal communications with other resources. This confirms that OPCA family subject litigation is unusual. 
The OPCA inter-partner family law Dispute Scenarios identified are summarized in Table 1, below.

TABLE 1

SUMMARY OF 10 OPCA INTER-PARTNER FAMILY DISPUTE SCENARIOS AND LITIGANTS ${ }^{232}$

\begin{tabular}{|c|c|c|c|c|c|}
\hline $\begin{array}{l}\text { OPCA } \\
\text { Person }\end{array}$ & A.B. & Curle & G.J. & Hill & J.M. \\
\hline Cases & $\begin{array}{l}2012 \text { QCCS } 6120 \\
2013 \text { QCCA } 282 \\
2013 \text { QCCA } 725 \\
2013 \text { QCCS } 4394\end{array}$ & $\begin{array}{l}10 \text { RFL (6th) } 327 \\
2014 \text { ONSC } 1077\end{array}$ & 2013 ВСРС 242 & $\begin{array}{l}2008 \text { SKQB } 11 \\
2008 \text { SKQB } 58\end{array}$ & 2010 SKQB 79 \\
\hline Gender & M & M & M & $\mathrm{F}$ & M \\
\hline $\begin{array}{l}\text { Movement / } \\
\text { Guru }\end{array}$ & "A4V" / - & $\begin{array}{c}\text { Detaxer \& } \\
\text { Freeman / } \\
\text { multiple gurus }\end{array}$ & Freeman / - & Detaxer / Lindsay & $\begin{array}{c}\text { Paradigm \& } \\
\text { Sovereign Citizen } \\
\text { / Porisky \& others }\end{array}$ \\
\hline $\begin{array}{l}\text { Dispute } \\
\text { Subject }\end{array}$ & Child custody & $\begin{array}{l}\text { Child custody / } \\
\text { debt (child } \\
\text { support) }\end{array}$ & Child custody & $\begin{array}{c}\text { Spousal support / } \\
\text { property }\end{array}$ & Child support \\
\hline $\begin{array}{l}\text { OPCA Role } \\
\text { Litigation }\end{array}$ & Factor in analysis & Attack \& defence & $\begin{array}{l}\text { Factor in } \\
\text { analysis }\end{array}$ & Attack & Defence \\
\hline ID? & $\mathrm{Y}$ & $\mathrm{Y}$ & $\mathrm{Y}$ & $\mathrm{Y}$ & $\mathrm{Y}$ \\
\hline $\begin{array}{l}\text { High } \\
\text { Conflict? }\end{array}$ & Y & Y & Y & - & $\mathrm{Y}$ \\
\hline $\begin{array}{l}\text { Conspiracy/ } \\
\text { Fringe? }\end{array}$ & - & $\mathrm{Y}$ & $\mathrm{Y}$ & $\mathrm{Y}$ & $\mathrm{Y}$ \\
\hline $\begin{array}{l}\text { OPCA } \\
\text { sphere? }\end{array}$ & - & $\mathrm{Y}$ & $\mathrm{Y}$ & Y & $\mathrm{Y}$ \\
\hline $\begin{array}{l}\text { Litigant } \\
\text { Type }\end{array}$ & Mercenary & $\begin{array}{c}\text { Fighter \& } \\
\text { Believer }\end{array}$ & $\begin{array}{c}\text { Fighter \& } \\
\text { Believer }\end{array}$ & Mercenary & $\begin{array}{c}\text { Fighter \& } \\
\text { Believer }\end{array}$ \\
\hline Profession & $\begin{array}{l}\text { Politician / } \\
\text { engineer }\end{array}$ & Engineer & Technical & Real estate agent & $\begin{array}{c}\text { Small business } \\
\text { operator }\end{array}$ \\
\hline Criminal? & - & $\mathrm{Y}$ & $\mathrm{Y}$ & - & $\mathrm{Y}$ \\
\hline Vexatious? & $\mathrm{Y}$ & $\mathrm{Y}$ & $\mathrm{N}$ & - & - \\
\hline Detaxer? & $\mathrm{N}$ & $\mathrm{Y}$ & $\mathrm{N}$ & $\mathrm{N}$ & $\mathrm{Y}$ \\
\hline
\end{tabular}

Table 1: Generally, "Y" and "N" is the presence or absence of a trait or feature; "-" is inadequate information for a conclusion. "OPCA Role Litigation" is how OPCA concepts were applied or relevant. "ID?" is whether the OPCA litigant was identified outside the litigation itself. "High Conflict" is whether the ex-partners engaged in high conflict behaviour. "Conspiracy / Fringe" is whether the OPCA litigant exhibited unusual belief systems. "OPCAsphere" indicates whether the OPCA litigant has adopted OPCAsphere beliefs. "Litigant Type" classifies OPCA litigants per Netolitzky "Attack on the Legal System," supra note 10 at 175-76. "Criminal" indicates the presence of a known criminal history. "Vexatious" indicates non-OPCA vexatious litigation misconduct. "Detaxer" denotes whether OPCA concepts were applied to avoid income tax obligations. 


\begin{tabular}{|c|c|c|c|c|c|}
\hline $\begin{array}{l}\text { OPCA } \\
\text { Person }\end{array}$ & Meads & Penney & R.L.L. & S.M. & T.C. \\
\hline Cases & 2012 ABQB 571 & $\begin{array}{c}2013 \text { NSCA } 126 \\
2014 \text { NSCA } 38 \\
2014 \text { NSSC } 411\end{array}$ & 2004 BCSC 580 & 2014 BCSC 2105 & $\begin{array}{c}2010 \text { NBQB } 192 \\
2012 \text { NBQB } 4 \\
2012 \text { NBQB } 376\end{array}$ \\
\hline Gender & $\mathrm{M}$ & M & $\mathrm{M}$ & M & M \\
\hline $\begin{array}{l}\text { Movement / } \\
\text { Guru }\end{array}$ & $\begin{array}{c}\text { Sovereign Citizen } \\
/ \text { - }\end{array}$ & Freeman / - & Freeman / - & Freeman / - & $\begin{array}{c}\text { Freeman / } \\
\text { Menard }\end{array}$ \\
\hline $\begin{array}{l}\text { Dispute } \\
\text { Subject }\end{array}$ & $\begin{array}{l}\text { Debt (child } \\
\text { support) }\end{array}$ & $\begin{array}{l}\text { Support / child } \\
\text { custody }\end{array}$ & $\begin{array}{l}\text { Child support / } \\
\text { costs }\end{array}$ & Child custody & Child custody \\
\hline $\begin{array}{l}\text { OPCA Role } \\
\text { Litigation }\end{array}$ & Defence & Defence & Defence & Defence & Factor in analysis \\
\hline ID? & $\mathrm{Y}$ & $\mathrm{Y}$ & $\mathrm{Y}$ & $\mathrm{Y}$ & $\mathrm{N}$ \\
\hline $\begin{array}{l}\text { High } \\
\text { Conflict? }\end{array}$ & $\mathrm{Y}$ & $\mathrm{Y}$ & - & $\mathrm{Y}$ & $\mathrm{Y}$ \\
\hline $\begin{array}{l}\text { Conspiracy/ } \\
\text { Fringe? }\end{array}$ & - & $\mathrm{N}$ & $\mathrm{N}$ & - & - \\
\hline $\begin{array}{l}\text { OPCA } \\
\text { sphere? }\end{array}$ & - & $\mathrm{N}$ & - & $\mathrm{N}$ & - \\
\hline $\begin{array}{l}\text { Litigant } \\
\text { Type }\end{array}$ & Mercenary & Mercenary & - & Mercenary & Mercenary \\
\hline Profession & $\begin{array}{l}\text { Technical/ } \\
\text { professional }\end{array}$ & Fisherman & - & $\begin{array}{c}\text { Technical/ } \\
\text { Professional }\end{array}$ & Truck driver \\
\hline Criminal? & - & - & $\mathrm{N}$ & $\mathrm{N}$ & - \\
\hline Vexatious? & $\mathrm{N}$ & $\mathrm{Y}$ & - & - & $\mathrm{N}$ \\
\hline Detaxer? & $\mathrm{N}$ & $\mathrm{N}$ & $\mathrm{N}$ & $\mathrm{N}$ & - \\
\hline
\end{tabular}

The low frequency of OPCA family litigation is not a surprise. While an increasingly large portion of family-related disputes involve SRLs, the OPCAsphere and its pseudolaw are illsuited to this domain. Most family law disputes between two former spouses or partners concern shared interests, such as access and custody of children, division of property of the relationship, or post-separation support. Put another way, these disputes relate to a bilateral agreement or arrangement between the two former partners. Legally, domestic relationships may result in equitable ${ }^{233}$ or statutory obligations. ${ }^{234}$ OPCA litigation is typically designed to evade criminal sanction or debt (from taxation or otherwise). The "Strawman" has little application to interpersonal conflicts.

\section{A. OPCA THEORY SUPPORTS INTER-PARTNER OBLIGATIONS}

Canadian pseudolegal theory emphasizes, rather than subverts, interpersonal bargains; it claims everything, including the relationship between the state and a private citizen, is a

234 See e.g. Divorce Act, RSC 1985, c 3 (2nd Supp); Family Law Act, SA 2003, c F-4.5 and other provincial equivalents. 
contract. This mischaracterization of the state and citizen relationship is a theoretical basis to avoid legislation and escape the government's and courts' jurisdiction to enforce societal rules. For example, the "everything is a contract" theory provides a mechanism to deny or "opt out" of government obligations such as paying tax ${ }^{235}$ or abiding by the Criminal Code..$^{236}$

However, this strategic orientation poses a challenge in a family dispute context. For example, it is difficult in this conceptual framework for a father to say he has no obligation to care for his child. Beyond what the law requires, parental contribution to child rearing and care is a broad-based and widely accepted social norm.

The result is that attempts to reframe inter-partner family law disputes in an OPCA context are, at best, awkward, and can even be nonsensical. For example, the apparently brief OPCA litigation period in the Penney $v$. Tufts dispute makes absolutely no sense, legally or pseudolegally. Penney apparently tried to invoke the "Strawman" versus flesh and blood person distinction to challenge the authority of the appeal Court in which Penney, himself, was attempting to conduct an essentially conventional appeal that concerned new evidence, credibility, inadequate representation, and unadjudicated issues ${ }^{237}$ Evaluated from an OPCA perspective, Penney's approach is simply nonsense. Whether the appeal was conducted by the child's father or his "Strawman" was irrelevant. It may have made pseudolegal sense for Penney to argue that he was outside the conventional court process, or that he had a "common law" (as that term is used by OPCA litigants) right to parent his child that trumps any court order. But that is not what Penney appears to have done.

Meads also illustrates the poor match between family law litigation and OPCA theory. This was not a divorce action, but an OPCA debt elimination scheme. It just happens that the debt obligation, present and future, flowed from the dissolution of a marriage. Meads instead clearly illustrates the limited potential application of OPCA concepts in an inter-partner dispute conflict. Consistent with OPCA theory that "everything is a contract," Dennis Meads accepted that parties may bind one another by mutual agreement. In a matrimonial context, that meant he did not contest that his wife had a right to part of the matrimonial property, nor did he deny an obligation to pay child and spousal support, though he framed his compliance as voluntary (and presumably as a "fair bargainer"), rather than due to any legal (or legislated) obligation. This dichotomy explains why Dennis Meads disputed that one of his now adult daughters was a child of the marriage. He did so on the basis that the Meads' other children had paid for their own post-secondary education. This daughter should not be treated any differently, however; Dennis Meads acknowledged a personal obligation, as a parent, to assist if necessary. ${ }^{238}$

This was the sole focus of the Detaxers, but also is an objective of the Freeman-on-the-Land movement: see Netolitzky, "History of the OPCA," supra note 2.

An increasing number of Freeman-on-the-Land affiliates attempt to use OPCA strategies as a "get out of jail free" card, as reviewed in Fearn, supra note 41 at paras 128-30. See also Netolitzky, "Attack on the Legal System," supra note 11 at 164.

Penney 1, supra note 101 at paras 7, 13; Penney 2, supra note 101 at paras 19, 24-26. Meads, supra note 3 at para 20. 
Meads' OPCA activities really then had only three foci. He:

1. acknowledged family obligations, but wanted those paid from his "Strawman's" secret "A4V" bank account;

2. wanted to keep his physical (flesh and blood) self within the common law, or in this case, "God's law," and not enter into contract (admiralty law or commercial law) by "joinder" with either the Court, his wife, or her lawyer; and

3. sought a court instruction that the Court and his wife access his "Strawman" account and discharge his matrimonial and support obligations from that source.

The intended result is that he would obtain a state-sanctioned divorce and be left alone. Dennis Meads wanted a court-ordered, socially accepted divorce, and appears to have recognized that as important. ${ }^{239}$ As far as he was concerned, his marriage was already annulled by his wife's infidelity. ${ }^{240}$ He hoped the Court would formalize that. He did not deny he had an obligation to his former partner and children, but instead sought enforcement from an alternative (and imaginary) source for those funds. OPCA-based debt elimination schemes that target government or institutions are very well developed, and are documented in many Canadian court judgments. Dennis Meads' innovation was not that he used unusual OPCA concepts, but rather he had attempted to apply them to his matrimonial obligations.

J.M. used the conventional OPCA "everything is a contract" pseudolegal concept to purportedly end his obligations to his ex-partner by her accepting the terms of a foisted unilateral agreement. J.M. "booby-trapped" a support payment cheque so that it was a contract offer. ${ }^{241}$ While arguably a "dirty trick" on his ex-partner, J.M. was still playing inside the OPCA rules, in that he and his ex interacted on the basis of contract. J.M. was later entirely uncooperative with court processes since, in his mind, he had already resolved his family-based obligations. He therefore denied the Court's authority and jurisdiction.

At first it seems that G.J.'s refusal to pay child support cannot be reconciled with the hypothesis that OPCA affiliates generally respond to their family-related obligations. G.J. adopted an obviously unproductive lifestyle that revolved around his fringe political beliefs and social affiliations. He refused to acknowledge his court-ordered support obligations. However, closer examination of S.H. v. G.J. reveals a different explanation. G.J. refused to pay because he and his ex-partner had entered into a 50/50 shared custody arrangement, arguing that "you can't take my kid away from me and expect me to pay."242 Reframed, G.J. and S.H. had independently come to a bargain on how to address the needs of their daughter: each would have the child half the time. When S.H. reneged on that arrangement and involved the courts, she breached that "contract." G.J. now had no obligation to pay anything to S.H. It should be noted that Judge Dyer in S.H. v. G.J. is explicit in finding that G.J. is a caring, though disorganized, father. ${ }^{243}$ G.J.'s attempts to parent his child were sincere. Judges

\footnotetext{
$239 \quad$ Ibid at para 22.

Ibid at para 16 .

CC v JM, supra note 146 at para 11.

SH $v$ GJ, supra note 169 at para 21 .

Ibid at paras 107-10, 132.
} 
who hear OPCA-related family law disputes sometimes indicate that these individuals do seem to have a genuine interest and concern towards their children. ${ }^{244}$ The callous, hostile response of J.M. appears atypical.

\section{B. NON-"STRAWMAN" OPCA STRATEgIES}

While the "Strawman" is ill-adapted to a spouse versus spouse or parent versus parent conflict, the same is not necessarily true for other commonplace OPCA pseudolegal motifs, particularly foisted unilateral agreements.

The absence of these strategies from identified partner versus partner disputes is therefore very interesting. There is no theoretical reason why one partner could not, for example, use the Three/Five Letters scheme to (allegedly) prove a fact or fix an obligation on the other partner. For example, Partner A could use this mechanism to challenge Partner B to prove that $\mathrm{B}$ had not concealed income in a corporation owned by B. Failure to complete the foisted requirements of a Three/Five Letters procedure would then (allegedly) mean that B admits the alleged undeclared income, and is also estopped from later challenging that admission in court. This approach is often used when OPCA litigants are in conflict with state ${ }^{245}$ and institutional actors, ${ }^{246}$ and even occasionally in a personal civil litigation context. ${ }^{247}$ The Three/Five Letters scheme is a flexible, multi-purpose tool. One OPCA criminal offender even claimed this was a valid mechanism to obtain legal consent to sexual activities with underage children! $!^{248}$

No examples of a Three/Five Letters strategy appears in the identified disputes, though this kind of scheme has many potential applications in a family partner versus partner conflict.

Similarly, no OPCA litigant appears to have foisted the otherwise nearly universal "fee schedules" on their former partners. ${ }^{249}$ Again, there is no conceptual obstacle to targeting "misconduct" in a family dispute context. For example, a hypothetical family dispute fee schedule might target failures to conform to child custody agreements, with predefined fines assessed when a child is not picked up or delivered on time. However, foisted unilateral agreements of this kind do not appear in any of the partner versus partner Dispute Scenarios.

Ibid at paras 107-108; TC 1, supra note 190 at para 30; Penney 1, supra note 101 at para 12. See Private Career Training Institutions Agency v Prana Yoga Teacher College Inc, 2013 BCSC 17, 2013 BCSC 17 (CanLII); Drosdovech v Ashfield, 2010 FC 858, [2011] 1 CTC 12 (reporting attempts to evade income tax debts); Boisjoli, supra note 41.

See Rogozinsky, supra note 41; Myers v Blackman, 2014 ONSC 5226, 2 PPSAC (4th) 318 at paras 6-8 [Myers] (reporting a precursor debt collection action); Royal Bank of Canada v Place, 2010 ABQB 733, 504 AR 230; Royal Bank of Canada v Skrapec, 2011 BCSC 1827, 2011 BCSC 1827 (CanLII), aff'd 2012 BCCA 10, 2012 BCCA 10 (CanLII); Stancer (Re), 2009 BCSC 398, 53 CBR (5th) 76; Whitfield $v$ Chrysler Credit Canada Ltd, 2001 ABQB 5, 2001 ABQB 5 (CanLII).

See e.g. Perreal, supra note 62; Rubbert, supra note 41.

This extremely disturbing application of OPCA pseudolaw is reported in $R v T L P, 2015$ BCSC 618, 2015 BCSC 618 (CanLII). Unsurprisingly, the foisted unilateral agreement scheme was categorically rejected as a defence to illegal sexual touching.

See Meads, supra note 3; Myers, supra note 246; Szoo’ v RCMP, 2011 BCSC 696, 2011 BCSC 696 (CanLII) for examples of these documents. 
Stranger still, these OPCA litigants are clearly familiar with the fee schedule concept. T.C.'s threats to bill police were almost certainly based on a fee schedule. ${ }^{250}$ Dennis Meads' pseudolegal materials included a fee schedule. ${ }^{251}$ In fact, the absence of partner-to-partner fee schedules is simply remarkable. These retaliatory intimidation documents are ubiquitous in other OPCA litigation. ${ }^{252}$

OPCA gurus teach a number of pseudolegal mechanisms such as " $\mathrm{A} 4 \mathrm{~V}$ " and promissory note schemes that will allegedly pay off debts. However, attempts to apply these "money for nothing" schemes against ex-partners are rare. Dennis Meads is the notable exception. A.B. used "A4V" in an attempt to pay off his mortgage debt. Why not do the same for his outstanding child support arrears when, theoretically, A.B.'s secret "Strawman" "A4V" account contained huge, readily accessible sums?

Again, these are broadly disseminated OPCA strategies. "Money for nothing" OPCA schemes are commonly encountered as debt elimination tools outside the family law context; debt elimination is the third most common general application of OPCA techniques. ${ }^{253}$

Commonplace "non-Strawman" OPCA theories therefore do have potential application in inter-partner disputes. Then why are they absent? One possible explanation is that most OPCA affiliates are aware that these alleged debt relief strategies are, in fact, ineffective. If so, then potential OPCA family law litigants are apparently comfortable employing ultimately futile pseudolegal schemes to frustrate the collection efforts of their ideological "enemy" - the hydra of government, big business, banks, and other institutions — but are unwilling to exploit fellow individuals, including their former partners, in the same manner. A fact that supports this hypothesis is that only rarely are OPCA schemes ever deployed in interpersonal, private debt scenarios. ${ }^{254}$ Arguably, that means this pattern is not restricted to family subject disputes, but instead reflects a larger target bias.

A second explanation is simply a lack of imagination. If so, Dennis Meads is an innovator. Although he was probably sold his "A4V" debt elimination scheme as an anti-bank or an anti-tax tool, Meads realized he could also potentially apply these procedures in a family law context. In contrast, most OPCA affiliates simply use the products they purchase for the purposes advertised. This may be a better explanation for the absence of non-"Strawman" OPCA tactics in partner-to-partner conflicts. As previously noted, there is no reason why the Three/Five Letters foisted unilateral agreement strategy could not, in theory, be used to (allegedly) crystallize contested facts in a family law dispute. This has occurred in other interpersonal disputes, such as a tort claim $^{255}$ and a parent versus state child custody dispute. ${ }^{256}$

If true, then the unimaginative application of OPCA concepts emphasizes how OPCA affiliates typically operate by rote, and are simply not that creative. The same is certainly true

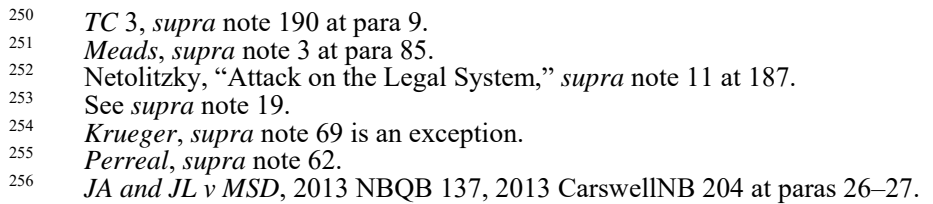


for their gurus. They rarely develop new concepts, but instead simply repackage or rearrange existing schemes. ${ }^{257}$

The comparatively low incidence of OPCA family litigation may simply indicate that no one in the OPCAsphere has yet made the leap and adapted its pseudolaw to fit this specific litigation domain. If true, that would be peculiar given the volume of family litigation and, therefore, the potential marketplace for these schemes.

\section{OPCA ARguments IN CHILd Custody DisPutes}

OPCA arguments are extremely rarely employed in parent versus parent custody disputes. This investigation identified only three examples, a negligible fraction of Canadian child custody litigation. As described above, this is not entirely unexpected given the focus of OPCA theory and the context in which OPCA schemes are promoted and sold.

The three instances where OPCA arguments were deployed in a parent versus parent custody dispute were marked by two other attributes: vexatious litigation conduct and high inter-parent conflict. In the series of Penney v. Tufts litigation, OPCA tactics emerged as part of a larger pattern of vexatious litigation. The overall litigation history, and the illogical application of a double or split person argument, suggests OPCA affiliation was just one of many different ways Penney attempted to prolong and frustrate his custody dispute.

Allan James Curle was formally declared a vexatious litigant, not merely for his OPCA affiliation, but more globally as a consequence of his persistent and futile litigation pattern. Unlike Penney's apparently brief flirtation with the OPCAsphere, the OPCA community and its concepts have dominated Curle's professional and personal life for at least a decade. ${ }^{258}$ This is not, however, the only context in which Curle has engaged in aggressive, persistent litigation. The "conventional" dispute with his former wife and business partners over the Norall Group engineering firms is equally tenacious. ${ }^{259}$

Less data is available on S.M., but the one reported judgment indicates not only strong inter-parent conflict, but also frequent returns to court. Nine enumerated orders were issued between 2006 and 2014, but Justice Blok indicated that these were only the "more pertinent" ones. $^{260}$

\section{OPCA AfFiliate SRLs ANd PARental Fitness}

In three other child custody disputes (involving G.J., T.C., and M.L.) one parent cited the other parent's OPCA affiliation as a negative factor that should cause the court to reduce or restrict child access. Notably, these OPCA affiliates neither advanced OPCA concepts as a basis for why they had a better claim on the children than their former partner, nor claimed they were outside the court's jurisdiction. Their OPCA conflicts were restricted to government, police, and the banks. 
These OPCA litigants were apparently willing to have "conventional" courts mediate and structure disputes about their inter-personal and inter-partner bargains. This may be a useful distinction that a judge could stress when adjudicating a partner-to-partner dispute that involves an OPCA litigant. In OPCA mythology, "conventional" courts are often identified as "courts of commerce." 261 If so, then an OPCA litigant's own belief system would dictate that the "marriage contract" falls into Canadian courts' jurisdiction and, whatever else, the OPCA litigant should live up to his or her side of the matrimonial bargain. This is an instance where a judge framing the dispute as a question of "fair dealing," rather than as an application of legislation, may lead to positive results.

The existence of this unexpected category challenges the narrative advanced by Macfarlane, where "typical SRLs" and OPCA litigants are distinct and separate groups. G.J., M.C., and A.B. appear instead to fall squarely into the population studied by the NSRLP. They engaged in illegal activities, but not in relation to their parental role and inter-spouse disputes. What, then, differentiates these SRLs from a parent with a criminal background?

Arguably, the distinction flows from the judiciary's very negative response to any OPCA affiliation and its implications for parental fitness. In all three instances, the Court concluded OPCA affiliation was relevant:

G.J.: Judge Dyer took what he acknowledged was an unusual step of making a court order that targeted the belief system of a parent. ${ }^{262}$

T.C.: Justice Walsh concluded that the emergence of Freeman-on-the-Land affiliation, and illegal activity on that basis, was a change in circumstances in what had previously been an inter-parent dispute that had favoured the father. ${ }^{263}$

A.B.: Justice Cullen interpreted A.B.'s "A4V" explanation as an indication of mental health issues, and this appears to be an important, if not decisive, factor as to why A.B.'s ex-spouse received custody of their children. ${ }^{264}$

In S.H. v. G.J., the Court concluded that exposing a child to OPCA concepts is a breach of a parent's responsibility "to instruct and encourage a child to understand the rule of law and even how to seek to change in a lawful way a rule or law that is felt to be unjust or outdated." 265 This same concern was identified in TC 3, where Justice Walsh critiqued the unnecessary exposure of T.C.'s "children to his public confrontations with the police,"266 and

OPCA gurus often teach an artificial distinction between their spurious variation on "common law" (see supra note 59), and the law applied by "de facto" (that is, "conventional") courts, which is stereotypically called "admiralty law," "commercial law," "merchant law," and "lex mercatoria," or combinations or variants thereof: see Koniak, supra note 59 at 83-87; Sullivan, supra note 33 at 804807; Menard, Lawful Excuse, supra note 33 at 124-29. See also Meads, supra note 3 at paras 127, $270-71$ for examples of how this concept is expressed. The result is that "conventional" "de facto" courts are (allegedly) limited to enforcing contract law, as part of the "everything is a contract" motif (see supra note 60 and the accompanying text).

262 SH $v$ GJ, supra note 169 at paras $136-66$.

263 TC 3, supra note 190 at paras 19-20.

$264 \quad A B 1$, supra note 208 at paras 6-10, 12, 111, 227.

265 Supra note 169 at para 162.

266 Supra note 190 at para 19. 
ordered that T.C. not expose his children to these concepts. ${ }^{267}$ The Court's response to A.B. employing OPCA "A4V" concepts was even more dramatic; this was a basis to deny custody, even though A.B. said he would not share these ideas with his children. ${ }^{268}$ Clearly, potential transmission of OPCA pseudolaw to children is a serious concern, though the judges involved do not comment on the larger OPCAsphere construct and its atypical contents.

The judiciary's reaction is perhaps unsurprising. OPCA ideas are a challenge to their area of authority and expertise. As a theoretical question, it is interesting to balance court responses to what could be considered bad ideology, ${ }^{269}$ versus other deficient parental conduct, such as a parent's failure to vaccinate a child. ${ }^{270}$

As the OPCA phenomenon becomes better characterized and understood, a parent's OPCA affiliation may plausibly cast an even larger shadow on how courts balance parental custody and access. A statistical connection may be established between OPCA affiliation and criminal misconduct. Reported OPCA litigation is often a defensive effort by criminals to evade justice. ${ }^{271}$ If so, will OPCA affiliation become a shorthand indication of bad character, analogous to substance abuse?

Similarly, if a parent spends much time in the OPCAsphere then that will mean exposure to, and probably acceptance of, minority views on government, institutions, health care, science, and, of course, conspiracies of all kinds. While mental health professionals have classified this as a kind of political belief, ${ }^{272}$ it is difficult to imagine that this characteristic will not be seen as a negative factor by at least some judges. What are the broader psychological implications of OPCA affiliation? Is OPCA affiliation a cause or effect of socially marginalized beliefs and associations? These, and other potentially relevant questions, await professional social science investigation of this population.

None of the OPCA Inter-Partner Dispute Judgments squarely address what has emerged as an important issue in criminal prosecution of OPCA litigants: can an OPCA litigant be trusted to follow court instruction? When dealing with accused persons and offenders, Canadian courts have, in certain instances, concluded that judicial interim release ${ }^{273}$ and

Ibid at para 59 .

$A B 1$, supra note 208 at paras 6-10, 12, 111, 227.

The key case on this issue is Young v Young, [1993] 4 SCR 3, 108 DLR (4th) 193, a dispute where the court refused to interfere with parent-to-child religious instruction. Judge Dyer in SH v GJ, supra note 169 at paras 145-66, was clearly conscious of the high threshold set in Young $v$ Young in his analysis of what restrictions should be placed on G.J.

Judicial response to this issue is inconsistent. Vaccination was ordered during an inter-parent disagreement in CMG v DWS, 2015 ONSC 2201, 58 RFL (7th) 376 and GM v SS, 2012 BCSC 1491, 2012 BCSC 1491 (CanLII), aff'd on other grounds 2013 BCCA 365, [2014] 1 WWR 729; Children's Aid Society of Peel Region v H(TMC), 2007 ONCJ 632, 49 RFL (6th) 229; Children's Aid Society of Peel Region v H(TMC), 2008 ONCJ 20, 50 RFL (6th) 461 (where a parent was a carrier of a chronic viral infection). Adoption was refused in Re Gainor, [1975] 6 WWR 130 (Alta QB) where the prospective parents rejected vaccination. However, other decisions have blocked child protection services' attempts to ensure vaccination (see CRB and SGB v Director of Child Welfare (Nfld) (1995), 137 Nfld \& PEIR 1 (Nfld SC (TD)); JP (Re), 2010 ABPC 379, 39 Alta LR (5th) 293), or only sanctioned vaccination where there was an imminent threat due to a disease outbreak (see e.g. Chmiliar v Chmiliar, 2001 ABQB 525, [2001] 11 WWR 386).

See supra note 236.

See Pytyck \& Chaimowitz, supra note 25; Parker, supra note 25.

See e.g. $R v$ ANB, 2012 ABQB 556, 570 AR 146; $R$ v Lavin, 2013 ONCJ 6, 2013 ONCJ 6 (CanLII); $R$ $v$ McCormick, 2012 NSCA 58, 317 NSR (2d) 273; $R$ v Blerot, 2014 SKQB 2, 2014 DTC 5029. 
conditional sentences ${ }^{274}$ are not appropriate. OPCA affiliates claim they are exempt from state and court authority. How can they be trusted? Arguably, the same is true for OPCA litigants in a family law dispute. That said, again, the fact that OPCA litigants identified in parent-to-parent disputes did not invariably claim to be outside any authority is interesting. Penney and S.M. denied or questioned court jurisdiction, but not Curle, G.J., T.C., and A.B. Instead, there seems to be a distinction between court and state jurisdiction.

\section{E. ATtRibutes OF OPCA Litigants IN FAMILY LAW DISPUTES}

A limited amount of information can be distilled about family subject OPCA litigants. The majority (nine of ten) are male. This gender imbalance is also true for OPCA litigation as a whole. Education and employment shows no obvious pattern. As expected, no one in the sample appears to have accidentally adopted OPCA strategies. Some clearly exhibit the "Mercenary" litigation pattern and had abandoned unproductive OPCA strategies (A.B., Meads, Penney, S.M., T.C.), while most others appear to be persistent "Fighters and Believers" OPCA litigants (Curle, G.J., Hill, J.M.). ${ }^{275}$

Three (A.B., Curle, Penney) clearly exhibit vexatious litigation patterns beyond their use of OPCA court strategies. ${ }^{276}$ Only one of the Dispute Scenarios (Hill) did not clearly involve high levels of inter-partner conflict. All members of the OPCAsphere (Curle, G.J., J.M.) had a history of criminal activity. Unexpectedly, only Curle and J.M. (two of nine) engaged in "detaxing." Though A.B. indicated he could use his "A4V" OPCA scheme to pay income tax, he apparently did not attempt to do so.

Of the nine instances where the OPCA litigants were identified, four (Curle, G.J., Hill, J.M.) exhibited unusual or extreme beliefs. None of the transient Mercenary OPCA family law litigants had that characteristic. ${ }^{277}$ This is consistent with the theory that Mercenary OPCA litigants have little interest in, or may be repulsed by, the OPCAsphere's web of conspiracy and atypical belief. ${ }^{278}$

This correlation illustrates how those embedded in the OPCAsphere are, simply put, unusual. This is a population which finds unorthodox concepts unexceptional or even attractive. Political scientist Barkun observes that in improvisational millenarian subcultures, the fact that certain information or "stigmatized knowledge" is generally rejected itself provides confidence that the rejected knowledge must instead be true. ${ }^{279}$ Why else would it be hidden or suppressed? This process is very obvious in the OPCAsphere. Minority beliefs are true because they are minority beliefs. Unconventional authorities (OPCA gurus), arcane

See e.g. $R$ v Jastrebske, 2013 SKQB 150, 419 Sask R 15 at paras 14-15, aff'd 2014 SKCA 127, 2014 SKCA 127 (CanLII).

275 See Netolitzky, "Attack on the Legal System," supra note 11 at 175-76 for an explanation of these terms.

276 As evaluated by the criteria collected in Chutskoff $v$ Bonora, 2014 ABQB 389, 590 AR 288 at paras 80-93 [Chutskoff]. See also Boisjoli, supra note 41.

277 Arguably, A.B. is an exception given his apparent aversion to child vaccination. This was the only unusual belief motif identified for A.B. beyond, of course, his willingness to advance the bizarre "A4V" and "Strawman" mythology.

278 Netolitzky, "Attack on the Legal System," supra note 11 at 179-81. 
information sources (150 year old legal dictionaries), and alternative media (YouTube videos) are reliable because they are marginalized by the "Powers That Be." This affinity for the fringe and irregular in many ways explains the success of OPCA gurus, despite their slapdash materials, amateurish presentation, and incoherence. ${ }^{280}$

Litigation sophistication varied widely, ranging from bald claims of special status (such as Penney invoking a "Strawman"-based immunity), reliance on pre-fabricated documents (such as A.B.'s debt elimination scheme), unusual applications of standard OPCA schemes (for example, Meads' use of "A4V" in a family law debt context), to creative adaptation and development of unique OPCA schemes (as seen in Curle's behaviours).

Curle deserves special mention as an uncommon OPCA litigant who, throughout his litigation, was sophisticated in both law and pseudolaw. The 2004 Curle v. Lowe lawsuit displays a full appreciation by Curle that he must respond to Canadian jurisprudence. ${ }^{281}$ Similarly, Curle's recent attempts to circumvent his vexatious litigant order and conduct a Charter challenge of child support legislation is, for a lay person, very well constructed and argued. The procedure is correct, his court documents are of high quality, and he faced and responded to actual Canadian law. At the same time, Curle's pseudolegal arguments are carefully constructed, though obviously still doomed to fail. Curle is therefore both a sophisticated legal and pseudolegal SRL. Most modern Freeman-on-the-Land OPCA litigants show little understanding of legal procedure and principles, and generally flail and founder when in court. Curle, however, is a product of the Detaxer subsociety. That community adopted a more detail- and procedure-oriented litigation approach. For example, their methods included searching for formal defects in government documents, and advancing "conventional" disclosure and evidence arguments to defend against prosecution.

\section{Conclusion}

This investigation demonstrates OPCA theories are only rarely employed in inter-partner family litigation, especially child-related disputes. That is likely no coincidence. The dominant OPCA pseudolegal concepts are typically intended and marketed as mechanisms that target government and institutional actors, not other private individuals. This means that OPCA schemes are functionally and contextually ill-adapted for application in many family law scenarios. They aim at a different enemy. This explains why Hamilton's hypothesis that OPCA litigation and family law litigation broadly overlap ${ }^{282}$ is incorrect.

A “conventional" SRL goes to court to use that institution's processes to resolve disputes with a former partner, rather than to claim extra-legal authority over a disputed child and, on that basis, reject court authority. However, unilateral empowerment is the central axis of the OPCA phenomenon. Pseudolaw (allegedly) permits persons to ignore the courts, trump state authority, and unilaterally impose (allegedly) binding demands on other parties, including modern Freeman-dominated OPCAsphere. Lindsay is too professional, knows too much actual law and procedure, carefully cites his sources, and builds his analysis using actual legislation and case law. Reframed, he is too "mainstream" to possibly offer effective pseudolegal solutions. 
state actors, institutions, and private individuals. OPCA affiliates employ OPCA theories to break conventional authority.

The unexpected aspect of this article is that the "normal SRL" population includes OPCA affiliates. This indicates OPCA affiliates are willing to "pick and choose" the kind and target of their OPCA schemes: G.J., T.C., and A.B. did not advance OPCA concepts in their family law disputes; Curle remained a "conventional" litigant in his business litigation. They obviously remained challenging court participants, but arguably were not vexatious, only antisocial.

The "conflation" risk proposed by Macfarlane ${ }^{283}$ remains entirely hypothetical. This author has failed to identify any instance where this risk has emerged, and it is hard to imagine how this confusion might occur. ${ }^{284}$ The surveyed cases show the fingerprints and conduct of OPCA litigation are very distinct. Instead, this study determined that "conventional" SRL and OPCA communities overlap, but in those circumstances, pseudolegal belief was identified as an undesirable personal characteristic. OPCA affiliation did not result in G.J., T.C., or A.B. being declared legally vexatious. A more plausible "conflation" scenario is where a Mercenary OPCA Litigant adopts and then discontinues OPCA litigation. However, the disputes reviewed ${ }^{285}$ illustrate that the judiciary had no difficulty distinguishing these two styles of self-represented litigation, and adjusted its response when these litigants switched gears. ${ }^{286}$ Instead, the "conflation" controversy appears to have confused SRLs. ${ }^{287}$

Whether OPCA affiliation by one partner triggers domestic discord, followed by relationship breakdown, is an interesting "cause and effect" question. This seems plausible. A.B. and T.C. illustrate how OPCA belief drives conflict with public and institutional actors, with negative consequences for the family as a whole.

Another important question is whether pseudolaw could potentially become more common in family law litigation. A useful approach to this possibility is to evaluate OPCA ideas as "memes": discrete ideas whose frequency and distribution in populations are selected in a manner analogous to how genes operate in a biological context. ${ }^{288}$ In brief, meme theory applies the principles of natural selection to ideas. Viewed in that context, OPCA ideas are pathogenic, parasitic, deleterious memes: they spread through populations, have a superficial

\section{Supra note 17.}

Jonnette Watson Hamilton \& Alice Woolley, “What Has Meads v Meads Wrought?” (8 April 2013), ABlawg (blog), online: <ablawg.ca/2013/04/08/what-has-meads-v-meads-wrought/> indicate that in Scotia Mortgage Corporation v Gutierrez, 2012 ABQB 683, 84 Alta LR (5th) 349 [Gutierrez] an individual, Derek Johnson, is identified as an OPCA litigant but no basis for that is provided. This is incorrect. Johnson had advanced the "no value provided" OPCA scheme that foists an obligation on a creditor to prove a debt. See Bloy, supra note 24; Rogozinsky, supra note 41 at paras 48-54. Gutierrez, ibid at paras 17-20 responds to this OPCA scheme. It appears Hamilton and Woolley were unaware of or unfamiliar with the OPCA concepts employed in this scenario.

$S B$ v SM, supra note $110 ; A B 1$, supra note $208 ; A B 3$, supra note 208.

The same is also true in other areas of law, see e.g. $R v$ Martin, 2012 NSPC 115, 323 NSR (2d) 376. See e.g. Chutskoff, supra note 276 at para 77.

This term and the general concept were first proposed in Richard Dawkins, The Selfish Gene (Oxford: Oxford University Press, 1976). This novel concept and its potential applications are the subject of a certain degree of academic controversy. While this article discusses the "OPCA meme," the technically correct term would be the "OPCA memeplex." A "memeplex" is a group of memes that have co-evolved and offer mutual support. For example, the "Strawman" concept is a discrete meme, but is critical to support other memes in the OPCA memeplex, such as the "A4V" "money for nothing" meme, and the meme of "opting out" of government authority. 
appeal, and provide no useful benefit to their host, instead inflicting serious harm. When viewed from a historical perspective, OPCA concepts exhibit a memetic epidemic pattern of emergence, spread, and collapse.

For example, in the US, OPCA concepts were first developed and sequestered in rightwing, racist groups, but rapidly spread through a vulnerable population of distressed rural and farm communities during the 1980 's farm crisis. ${ }^{289}$ A similar "spreading infection" pattern is ongoing in the Republic of Ireland and the UK in response to debt-based stresses and a property bubble. The predictable endpoint of this process is a collapse in public interest in OPCA concepts once they prove ineffective. Many people adopt OPCA schemes to get a benefit. When the comparatively apolitical Detaxer movement proved useless, there was no reason for its largely Mercenary population to remain interested. The Detaxer strain of the OPCA parasitic meme went all but extinct.

This raises an interesting question: could OPCA concepts enter into the large SRL family dispute population and cause a new cycle of infection?

In brief, probably not. The current pattern where family issue OPCA litigation is rare seems likely to continue. The collection of pseudolegal concepts propagated in the OPCAsphere is remarkably conservative, and so it is unlikely that new family-specific litigation motifs may emerge. ${ }^{290}$ At present, OPCA gurus and affiliates appear all but hypnotized by the dominant "Strawman" split or double person paradigm, which has little relevance in a family dispute context. While "money for nothing" and foisted unilateral agreement schemes have potential application in partner-to-partner conflicts, using these concepts against a former partner is not part of the OPCAsphere's social construct. Government, law enforcement, and "the Banksters" are evil, not other ordinary people.

A poorly documented social movement of male parents who perceive that they are unfairly treated by the courts in disputes with their spouses, typically over parental fitness and custody, is one potentially suitable host population for a future OPCA family laworiented infection. ${ }^{291}$ This unfairness is frequently couched in an ideological framework: that the courts have adopted a political feminist or anti-male agenda, and make decisions on that policy basis. This "Fathers' Rights" movement is a new potential host population for the OPCA phenomenon, as pseudolaw provides an apparently powerful tool to subvert court authority (the "Strawman"), and a mechanism to enforce a superior extra-legal claim on "the enemy," mothers, via tools such as foisted unilateral agreements. (New York: Viking Penguin, 1990).

290 Netolitzky, "History of the OPCA," supra note 2 at 636.

291 This phenomenon appears to have attracted little English language academic commentary. An interesting exception is Pierrette Bouchard, Isabelle Boily, \& Marie-Claude Proulx, School Success by Gender: A Catalyst for the Masculinist Discourse (Ottawa: Status of Women Canada, 2003). This report included a survey of Fathers' Rights groups. The creator of one website sued in defamation, but the report was deemed a fair comment: Wiebe v Bouchard, 2005 BCSC 47, 46 BCLR (4th) 278; Wiebe v Bouchard, 2008 BCSC 249, 58 CCLT (3d) 114. Reported cases where these groups are a factor include: Bains v Bains, 2009 BCSC 1666, 2009 BCSC 1666 (CanLII); Paleczny v Paleczny, 2010 BCSC 36, 2010 BCSC 36 (CanLII); Label v Albanese, 2008 BCSC 1223, 61 RFL (6th) 182. 
Introduction of the OPCA meme into the Fathers' Rights population would, however, require a fundamental restructuring of the larger narrative in which Canadian OPCA theories are framed. The current Freeman-dominated OPCAsphere is egalitarian in its treatment of the genders. Infection of the Fathers' Rights movement would need a new guru to extract OPCA theories from their current conspiratorial context, and resettle those in an inter-gender battleground where powerful (and presumably malevolent) state actors are allied with feminists to deny fathers their rights and a proper role in their children's lives. ${ }^{292}$ An "interhost leap" of this scope is not unprecedented. There are at least two historic examples where predominately right-wing, white, racist, anti-authoritarian Sovereign Citizen concepts were resettled into a very different host population:

1. Robert Menard repackaged and introduced Sovereign Citizen OPCA memes into the leftist, anti-government, ecologically and environmentally focused, "hippy" and "occupista" Freeman-on-the-Land movement.

2. The Moorish Law movement hosted in urban black populations adopting Sovereign Citizen memes.

Radical "inter-species leaps" of this kind appear to be rare as, worldwide, the spread of OPCA concepts has only provided a few examples of a dramatic shift in the resident conspiracy culture. That said, as Menard has demonstrated, all that it takes to "infect" a hitherto isolated and unexposed host population is the right guru: a person who identifies pseudolaw as a tool that may fit into a new setting, with a willingness to exploit that vulnerable population to his or her advantage and the necessary skills to sell the victims on the OPCA product.

Hopefully, no "Pied Piper" of this kind emerges with an OPCA-based tune that tempts any part of the family SRL community. Given the apparently seductive character of these ideas, this is perhaps a point of concern that should be monitored by legal academics and other legal professionals who advocate for the interests of family law SRLs. ${ }^{293}$ The simple fact is that the courts cannot head off or immunize against an "infection" of this kind. Their role is reactive. It would be tragic if the large-scale misery inflicted by OPCA gurus and their products were to, somehow, spread into family subject litigation in a broad-based manner. ${ }^{294}$

292 The existing Fathers' Rights community exhibits anti-state and anti-court rhetoric. For example, the news stories featured on the (now defunct) Fathers Canada for Justice website, Fathers Canada, online: $<$ www.fathers.ca $>$ mention a New World Order, chemtrials, and broad-based conspiracies. This larger social construct contains the ahistorical and conspiratorial substrate where OPCA pseudolaw roots. The Fathers Canada website also indicates that its operators are exposed to, and sympathetic with, the Detaxer movement. See Fathers Canada, online: <http://www.web.archive.org/web/201409111 80935/http://fathers.ca/News/WhenTheMediaBecomesTheFourthEstate/WhoareCanadasfreemen.aspx>. See also Trust Christ or Go to Hell!, online: <www.trustchristorgotohell.org $>$, which is an Alberta Fathers' Rights movement website, and which cross-references many extreme political, conspiratorial subjects, including OPCA groups. The anti-judicial rhetoric on this website is extraordinary, though in something of an ironic twist, the operator of Trust Christ singles out Associate Chief Justice Rooke, arch-nemesis of the OPCA movements, for praise in his fair handling of an inter-parent child dispute. Netolitzky, "History of the OPCA," supra note 2 at 641-42.

Ibid; Netolitzky, "Attack on the Legal System," supra note 11 at 190. Parlee, supra note 41, provides a recent disturbing example of this phenomenon in a debt and foreclosure scenario. 